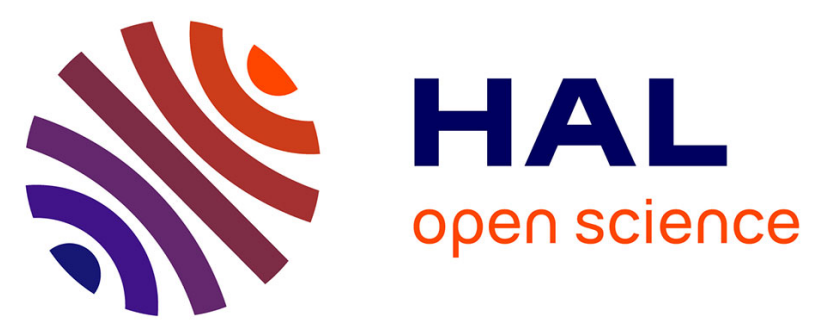

\title{
Fluvial Regimes, Morphometry and Age of Jezero Crater Paleolake Inlet Valleys and their Exobiological Significance for the 2020 Rover Mission Landing Site
}

Nicolas Mangold, Gilles Dromart, Véronique Ansan, Francesco Salese, Maarten Kleinhans, Marion Massé, Cathy Quantin-Nataf, Kathryn Stack

\section{To cite this version:}

Nicolas Mangold, Gilles Dromart, Véronique Ansan, Francesco Salese, Maarten Kleinhans, et al.. Fluvial Regimes, Morphometry and Age of Jezero Crater Paleolake Inlet Valleys and their Exobiological Significance for the 2020 Rover Mission Landing Site. Astrobiology, 2020, 20 (8), pp.994-1013. 10.1089/ast.2019.2132 . hal-02933200

\section{HAL Id: hal-02933200 \\ https://hal.science/hal-02933200}

Submitted on 8 Sep 2020

HAL is a multi-disciplinary open access archive for the deposit and dissemination of scientific research documents, whether they are published or not. The documents may come from teaching and research institutions in France or abroad, or from public or private research centers.
L'archive ouverte pluridisciplinaire HAL, est destinée au dépôt et à la diffusion de documents scientifiques de niveau recherche, publiés ou non, émanant des établissements d'enseignement et de recherche français ou étrangers, des laboratoires publics ou privés. 


\title{
ACCEPTED paper in Astrobiology
}

\section{Fluvial Regimes, Morphometry and Age of Jezero Crater Paleolake Inlet Valleys and their Exobiological Significance for the 2020 Rover Mission Landing Site}

\author{
N. Mangold ${ }^{1}$, G. Dromart ${ }^{2}$, V. Ansan ${ }^{1}$, F. Salese ${ }^{3,4}$, M.G. Kleinhans ${ }^{3}$, \\ M. Massé1 , C. Quantin², K.M. Stack ${ }^{5}$
}

\footnotetext{
${ }^{1}$ Laboratoire Planétologie et Géodynamique, UMR6112 CNRS, Nantes Université, Université Angers, 44322 Nantes, France;

${ }^{2}$ Laboratoire de Géologie de Lyon, ENSLyon, Université Claude Bernard, CNRS, Lyon, France;

${ }^{3}$ Faculty of Geosciences, Utrecht University, Utrecht, The Netherlands;

${ }^{4}$ International Research School of Planetary Sciences, Università Gabriele D’Annunzio, Pescara, Italy.

${ }^{5}$ Jet Propulsion Laboratory, California Institute of Technology, Pasadena, USA
}

Keywords :

Mars, Perseverance rover, landing site, HiRISE, HRSC, fluvial landforms 


\begin{abstract}
Jezero crater has been selected as the landing site for the Mars 2020 Perseverance rover because it contains a paleolake with two fan deltas, inlet and outlet valleys. Using the data from the High Resolution Stereo Camera (HRSC) and the High Resolution Imaging Science Experiment (HiRISE), a quantitative geomorphological study of the inlet valleys of the Jezero paleolake has been conducted. Results show that the strongest erosion is related to a network of deep valleys that cut into the highland bedrock well upstream Jezero crater, and that likely formed prior to the formation of the regional olivine-rich unit. In contrast, the lower sections of valleys display poor bedrock erosion and a lack of tributaries, but are characterized by the presence of pristine landforms interpreted as fluvial bars from preserved channels, which discharge rates have been estimated at $10^{3}-10^{4} \mathrm{~m}^{3} \mathrm{~s}^{-1}$. The valleys' lower sections postdate the olivine-rich unit and are linked directly to the fan-deltas, thus formed in an energetic, late-stage of activity. Although a Late Noachian age for the fan-deltas' formation is not excluded based on crosscutting relationships and crater counts, this finds evidence of a Hesperian age with significant implications for exobiology.
\end{abstract}




\section{Introduction}

Jezero crater has been interpreted as a paleolake due to the presence of two inlet fluvial valleys linked to two depositional fans and one outlet valley on the other side of the crater (Fassett and Head, 2005, Schon et al., 2012, Goudge et al., 2015). Jezero crater $\left(18.2^{\circ} \mathrm{N}, 77.6^{\circ} \mathrm{E}\right)$ is located east of Nili Fossae, west of the Isidis Planitia, and north of Syrtis Major Planum volcanic province, in a region dominated by a mafic ancient crust broadly associated with clay minerals indicative of a substantial aqueous alteration (e.g., Poulet et al., 2005, Mangold et al., 2007, Mustard et al., 2007, Ehlmann et al., 2008a, Mustard et al., 2009, Tarnas et al., 2019). Orbital spectrometers indicate the presence of carbonates throughout the region and inside Jezero crater (Ehlmann et al., 2008a). These characteristics made this paleolake a landing site of great interest for in-situ studies and potential sample return (Ehlmann et al., 2008b, McLennan et al., 2011, Goudge et al., 2015, 2017, Salvatore et al., 2018), and led to the selection of Jezero crater as the landing site for the next NASA mission, Mars 2020, planned for launch in 2020. An important aspect of landing site selection for the Mars2020 mission was the identification of deposits with high potential to preserve possible biosignatures and organic compounds that could be investigated in-situ and cached by the Mars 2020 Perseverance rover.

Jezero crater has been studied for more than a decade, but the timing and duration of its fluvial and lacustrine activity are still poorly constrained. Much work has been focused on the western delta within Jezero crater, with duration estimates for delta deposition and lake persistence varying from several years to millions of years, depending on studies and parameters used (Fassett and Head, 2005, Schon et al., 2012, Goudge et al., 2015). The fluvial valleys that fed the crater lake have also been mapped and described by previous studies (Fassett and Head, 2005, Mangold et al., 2007, Goudge et al., 2015), but these valleys have received much less attention than the paleolake and associated fan-delta deposits. Analysis of these valleys has the potential to provide new constraints on the relative timing and duration of aqueous activity in Jezero crater, thereby helping to clarify and possibly resolve uncertainties regarding the climate during the deposition of the Jezero deposits, and the persistence of conditions suitable for habitability at the surface. Such constraints are critical for assessing and understanding the astrobiological potential and relevance of Jezero crater and samples collected at this site.

In this study, a geomorphologic approach is used to qualitatively and quantitatively analyze the fluvial activity that enabled the deposition of the fan-deltas inside Jezero crater. We analyze the morphometry of the valley networks, including transverse and longitudinal profiles, estimate discharge rates of observed channels, and analyze their stratigraphic relationships with surrounding landforms and lithological units. These results provide new constraints on the formation of the fandeltas in Jezero, including the age and timescale of the paleolake activity, while a study focused on the delta formation will further estimate the minimum lifespan of the Jezero delta (Salese et al., 2019a) using hydrological models of Kleinhans (2005, 2010). We conclude our study with a summary of the exobiological implications of our results for the Mars 2020 Perseverance rover's exploration in Jezero crater. 


\section{Datasets and methods}

Data used in this study include visible images acquired for this region, including High Resolution Stereo Camera images (HRSC, Neukum et al., 2004), images from the Context Camera (CTX, Malin et al., 2007) and High Resolution Imaging Science Experiment images (HiRISE, McEwen et al., 2007). Mosaics of these images were assembled in a Geographic Information System (GIS) enabling morphometric measurements and mapping. This study's morphologic assessment is placed into a broader mineralogical and lithological context using previous studies' observations from infrared spectrometers in the Nili Fossae region (Poulet et al., 2005, Mangold et al., 2007, Ehlmann et al., 2008b, Mustard et al., 2009, Goudge et al., 2015, 2017).

Regional topography was obtained from the Mars Observer Laser Altimeter (MOLA, Smith et al., 1999) and from Digital Elevation Models (DEMs) calculated from HRSC stereo images (Gwinner et al., 2010, Ansan et al., 2013). For local observations of the Jezero crater entrance, DEMs were constructed using HiRISE stereo image pairs and CTX stereo image pair (see figure captions for image numbers). The resulting DEMs have been sampled with a spatial resolution of $1 \mathrm{~m} /$ pixel for HiRISE and $10 \mathrm{~m} /$ pixel for CTX. These DEMs were produced by stereo-photogrammetry using "Socet set" software (Kirk et al., 2008).

Estimations of channel discharge rates Q require the knowledge of the channel width $\mathrm{W}$ and depending on methods, the local slope s, channel height $\mathrm{H}$ and empirical laws. Fassett and Head (2005) used the method developed by Irwin et al. (2005) based on the empirical knowledge of valley widths on Earth (Osterkamp and Hedman, 1982) and accounting for Mars gravity:

$$
\mathrm{Q}=1.44 \mathrm{~W}^{1.22}
$$

A second method is based on the Manning equation initially developed for estimating discharge rates for pipelines with a correction for Mars gravity (e.g., Komar, 1979, Wilson et al., 2004):

$$
\mathrm{Q}=\mathrm{A}\left(\mathrm{g}_{\mathrm{M}} \cdot \mathrm{s} \cdot \mathrm{R}^{4 / 3} / \mathrm{g}_{\mathrm{E}} \mathrm{n}^{2}\right)^{1 / 2}
$$

In this relation, $\mathrm{A}$ is the flow cross-sectional area, $\mathrm{g}_{\mathrm{M}}$ and $\mathrm{g}_{\mathrm{E}}$ are gravity on Mars and Earth, respectively, the local slope $\mathrm{s}$ is measured from topography, $\mathrm{n}$ is the Manning roughness coefficient and $\mathrm{R}$ is the hydraulic radius, defined as the ratio of the flow cross-sectional area to the wetted perimeter. A and $\mathrm{R}$ are calculated assuming a rectangular shape using the valley channel height $\mathrm{H}$ and width $\mathrm{W}$. The friction coefficient $\mathrm{n}$ is fixed to 0.545 , a value assumed to represent coarsegrained, clast-rich channel beds for Mars as defined by Wilson et al. (2004). Smaller values are plausible for sandy beds, as expected for fluvial bars, but smaller values of $n$ would increase the discharge rates. Thus, we choose to keep the parameter at the upper bound to keep discharge rates estimated as lower bounds. A third terrestrial method uses the Darcy-Weisbach equation (Silberman et al., 1963). Although less popular than Manning, this equation has been applied on several Martian fluvial systems (e.g., Kleinhans et al., 2005, 2010; Roda et al., 2014; Salese et al., 2016), and is especially useful when estimations of the grain size distribution can be done and is potentially more accurate than Manning (Wilson et al., 2004):

$$
\mathrm{Q}=\mathrm{A}\left(8 \mathrm{~g}_{\mathrm{M}} \mathrm{Rs} / \mathrm{f}\right)^{1 / 2}
$$

where $\mathrm{f}$ is a friction factor established according Kleinhans (2005) following another semi-empirical law:

$$
(8 / f)^{1 / 2}=2.2\left(\mathrm{H} / \mathrm{D}_{50}\right)^{-0.055} \mathrm{~s}^{-0.275}
$$


where $D_{50}$ is the mean grain size diameter. We will use for $D_{50}$ the value measured in the conglomerates of Gale crater at $0.01 \mathrm{~m}$ (Williams et al., 2013). Although this value has no reason to apply everywhere on Mars, it is the only known ground truth yet. We will provide results from the three methods to enable cross-comparisons.

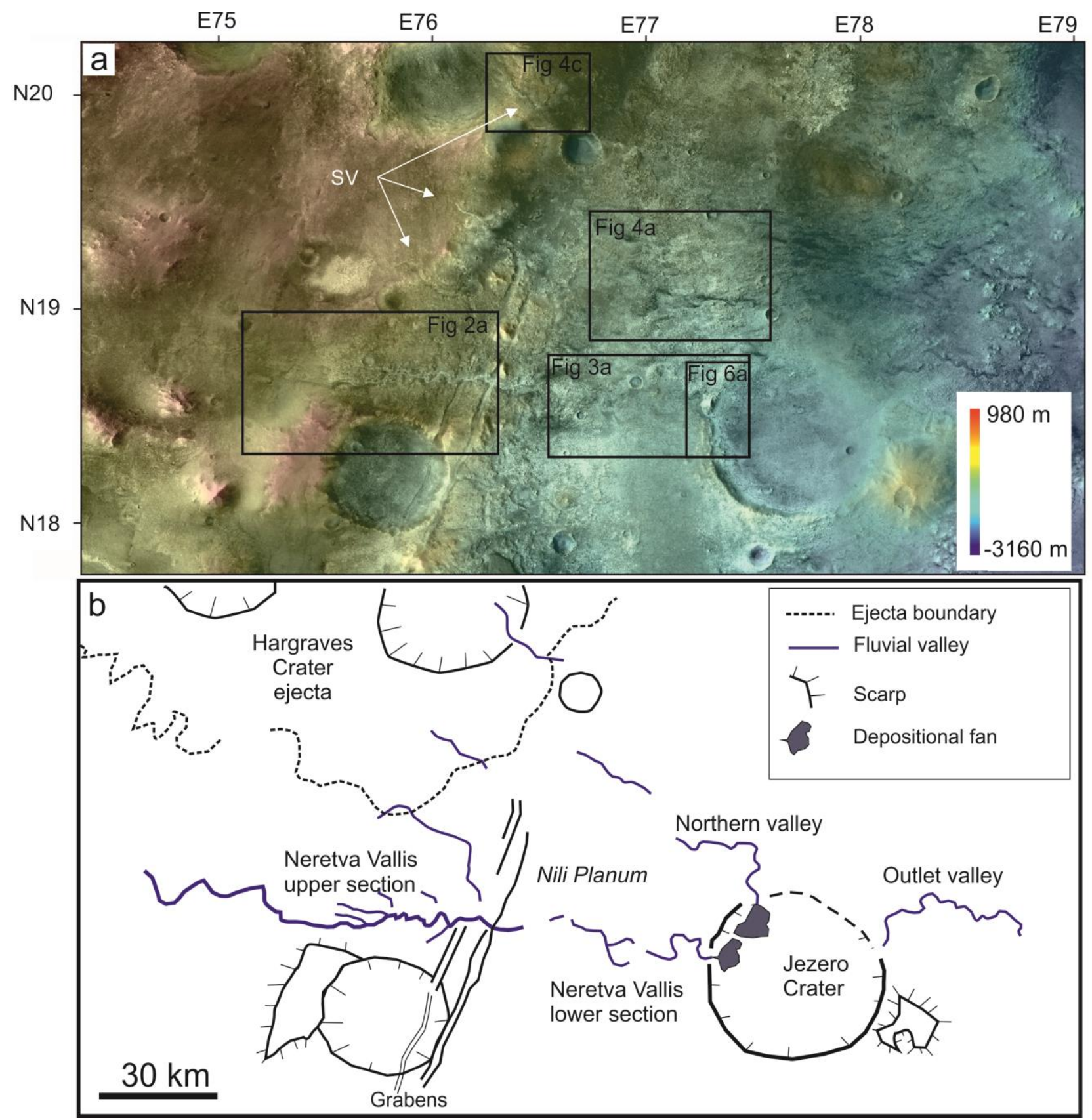

Figure 1: (a) CTX mosaic merged with color topography (MOLA data) with Jezero crater at the eastern side. SV: Small valleys without clear connection with the two main valley systems. (b) Simplified geomorphic map of the same area with all features of interest discussed in the study. Two fluvial valleys connect into Jezero crater, including Neretva Vallis to the west. Hargraves crater is located further north outside the boundary of this map. Its ejecta were identified by grooved terrains. 


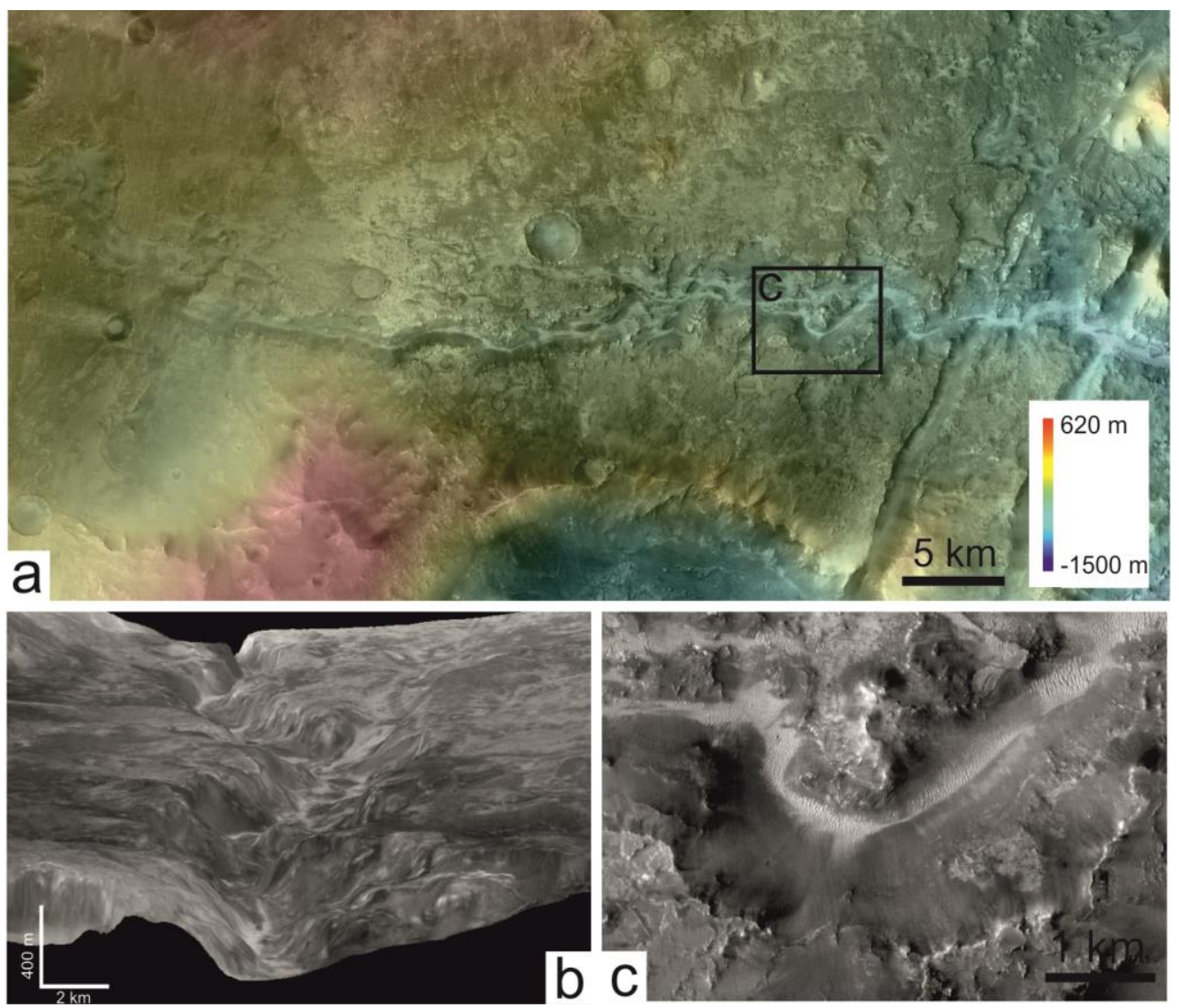

Figure 2: (a) Deepest part of Neretva Vallis (CTX mosaic merged with color HRSC data DEM in transparency, orbits 988 and 1347). (b) Westward 3D view looking upstream in the western valley network displaying a $400 \mathrm{~m}$ deep canyon. (c) CTX close-up on a sinuous part of the valley. Note the light-toned transverse dunes on valley floor.

\section{Morphological analysis of fluvial valleys linked to Jezero crater}

\subsection{Morphology and topology of valley networks}

Two fluvial valleys enter into Jezero crater, Neretva Vallis to its west and an unnamed valley to the north (Fassett and Head, 2005). The basic morphology of these valleys is described first, followed by a presentation of more quantitative parameters.

\subsubsection{Inlet valleys}

The main tributary of Neretva Vallis extends over $\sim 200 \mathrm{~km}$ west of Jezero crater (Figure 1). This valley is linked to several secondary tributaries ranging in length from 2 to $50 \mathrm{~km}$. This valley network presents a Strahler-order value of 3, indicating a network with low to moderate branching. The surrounding highlands are strongly etched by wind, suggesting that the smallest tributaries might have been degraded by this erosion and are not identifiable.

Over the westernmost $130 \mathrm{~km}$, Neretva Vallis display deep canyons with steep walls (maximum depth of $400 \mathrm{~m}$ ), corresponding to substantial incision (Figure 2). The main tributary valley is 
sinuous, and characterized by the presence of a few bends comparable to valley meanders (Figure 2c). Some tributaries appear to be short in length $(<20 \mathrm{~km})$ and display relative steep valley heads but the main tributary is much more elongated and does not present an amphitheater-shaped valley head. The lack of inner channels on the floor of these valleys limits the identification of the fluvial regime. The floor is frequently covered by eolian bedforms (Figure 2c) limiting the identification of channels in this upper section.

The easternmost $70 \mathrm{~km}$ of Neretva Vallis has a distinct morphology compared to the first $130 \mathrm{~km}$. Its course carves into a hilly bedrock with varying widths (from $200 \mathrm{~m}$ to $3 \mathrm{~km}$ ) (Figure 3). Overall, the following observations show that the valley presents patterns that resemble more individual channels with local sedimentary deposits than a bedrock valley with a prolonged erosion from plenty of streams. Firstly, the $70 \mathrm{~km}$ section of the main valley displays a flat floor and a rectangular side with apparent shallow depths $(<<50 \mathrm{~m})$ and a lack of branching tributaries. Secondly, elongated landforms of a homogeneously dark-toned material are present along the course of the valley in several locations (Figures 3b-f), although eolian bedforms hide partly the valley floor. These elongated landforms are several hundreds to a few kms in length for a few tens of meters in width. Their location, size and aspect are consistent with fluvial longitudinal bars. These landforms are not observed locally on the floor of the valley, but are found consistently along and over its whole width (Figures 3c-e), which means that the fluvial pattern is closer to the features classically observed for channels than to those of a fluvial valley incising bedrock. Assuming these landforms are fluvial bars, the flowing river would have been marked by successive divisions and rejoinings, as classically observed for braided rivers. This category of channel pattern can be referred to a moderately-braided type, i.e. low braiding parameter of about 1, such as defined by Rust (1978). Thirdly, fluvial deposits have accumulated along a $3 \mathrm{~km}$ wide area visible in Figure 3c (black arrows in Figure 3d). These deposits are partly etched by wind but they are sufficiently preserved to enable recognition and interpretation of fluvial bars (Figure 3e-f) while the valley, as a topographic depression, is no more visible in the topography, i.e. the deposits have spread over this location without eroding the bedrock. At this location, the deposits are likely the result of an amalgamation of deposits from several channels, or an accumulation of streams having spread laterally as observed for braided rivers (e.g. Reading, 1996). Note that the dark material presents $10 \mathrm{~m}$ scale regular polygons as frequently observed in Martian sedimentary deposits (e.g., El Maarry et al., 2012). Fourthly, in one location (Figure 3e), the fluvial patterns divide in two branches to the East and to the South. The eastern branch seems to be the first to have formed, because the E-W trending bars have been buried beneath the sediments from the N-S fluvial deposits (left of Figure 3e). Such a change in flow direction is typically observed for channels with avulsions due to variations in discharge rates or sedimentary deposits accommodation, while it is uncommon for a fluvial valley to divide in two branches in the downstream direction rather than the contrary, i.e. valleys branch together going downstream, but do not divide (e.g., Knighton, 1998). Thus, the morphology of the lower part of Neretva Vallis is dominated by patterns typical of channels without a significant erosion of the bedrock, strongly contrasting with the style of the deep valleys observed in the upper $130 \mathrm{~km}$ of Neretva Vallis.

The main tributary north of Jezero crater extends over $\sim 80 \mathrm{~km}$ (Figure 1). Due to extensive surface erosion and poor incision of the valley within the substrate, this valley appears discontinuous at times, preventing a continuous trace from upstream to downstream. It is a poorly developed system showing only one minor tributary. As for the lower $70 \mathrm{~km}$ of Neretva Vallis, the northern valley does 
not show a well-defined topography (Figure 4a). This valley develops into hilly bedrock with a rectangular shape, steep decameter-high sides and flat floor. Although the extensive eolian bedforms on the floor complicate the interpretation, the northern valley displays elongated patterns also interpreted as fluvial bars, because they are similar in shape and amplitude (several 100s of meters in length) to those observed in the lower section of Neretva Vallis (Figure 4b). Here too, the presence of bars suggests that the valley was formed by a channel that occupied the whole width of the valley. These similarities in size, shape and style suggest that the northern valley and the lower $70 \mathrm{~km}$ of the western valley formed under the same processes and potentially coevally. The faint aspect of the northern valley does not allow us to determine an accurate amount the eroded volume or crosssections, so we limit further quantitative developments to Neretva Vallis in sections 3.2 and 3.3.

\subsubsection{Other fluvial landforms}

In addition to these two main valley systems, small valleys (10 to $30 \mathrm{~km}$ long) are observed at the edge of Hargraves crater ejecta (Figure 1, SV crossing the East of the Hargraves ejecta (Figure 4cd). These valleys are oriented towards the preferential slope as are all fluvial valleys, confirming their origin, but they lack tributaries and outlets. The valleys are located in places where ejecta from Hargraves created a rough pattern to the SW direction. However, the valleys are filled by eolian material and it is unclear whether or not they cut the ejecta. Thus, it is unclear whether these valleys formed before or after these ejecta. Because of their discontinuous shape, it is also unclear whether these valleys were once linked to the main valley networks and connected to the Jezero crater depositional fan-deltas.

The outlet valley east of Jezero crater, displays a channel-like style over $70 \mathrm{~km}$ with a relief of 800 $\mathrm{m}$ from head to outlet. This valley decreases in width with distance to its end. The outlet valley was not investigated in this work but has been included in a numerical model and evolutionary scenario of Jezero basin (Salese et al., 2019a). This valley is generally interpreted as due to short-duration episode(s) related to the breach of the crater to the East and corresponding to short release(s) of water $(<<100$ years, Holo and Kite, 2017).

\subsubsection{Watershed areas and drainage densities}

Drainage density is a useful parameter to provide a quantitative estimation of the fluvial activity compared to other locations on Mars or Earth. The drainage density is the ratio of the total valley length over the watershed area. Fassett and Head (2005) estimated the total basin area from the sum of both northern and western watersheds to be $\sim 15,000 \mathrm{~km}^{2}$. More recently, Goudge et al. (2015) estimated the catchment of the western valley as $12,000 \mathrm{~km}^{2}$ and that of the northern valley as $18,700 \mathrm{~km}^{2}$. These estimations have been made by a method of automatic topography extraction with the hypothesis that the Hesperian age Hargraves impact crater formed after the fluvial activity (Goudge et al., 2015); the basin defined from actual topographic divide being smaller than these estimations. Because the relationships between fluvial valleys and Hargraves crater are unclear, we use manual observations of the valley heads independent of Hargraves crater to provide more conservative estimations of catchment areas. Our analyses define a smaller catchment area of 6,500 $\mathrm{km}^{2}$ for the western watershed (Neretva Vallis). The drainage density inferred for the western watershed is thus of approximately $0.05 \mathrm{~km}^{-1}$. The lack of tributaries for the northern watershed prevents constraint of the basin extension and the drainage density. 

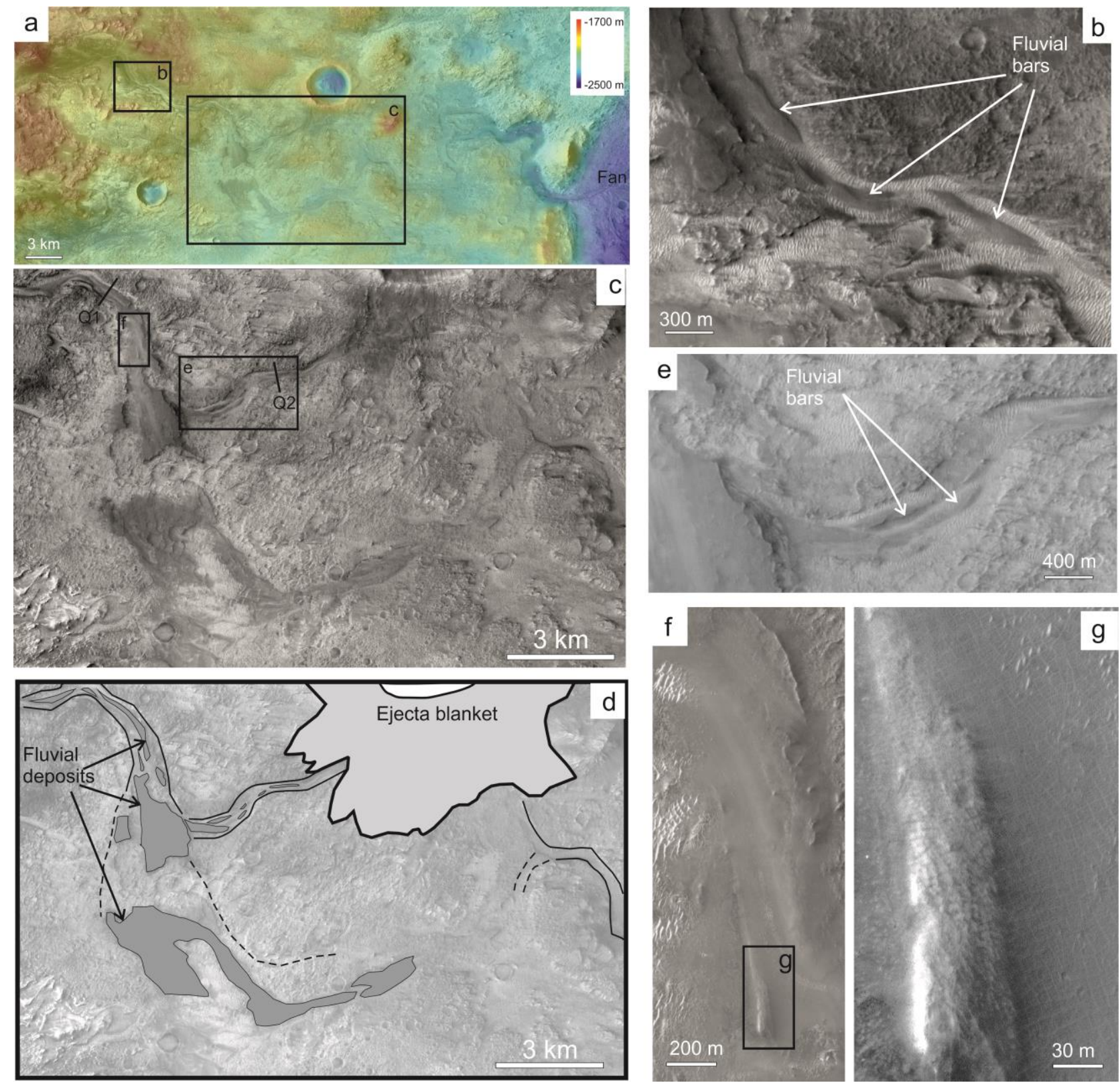

Figure 3: (a) Lower section of Neretva Vallis (CTX mosaic merged with color HRSC DEM in transparency). The flow is from left to right. (b) Close-up showing the presence of elongated interior deposits interpreted as fluvial bars. The valley floor is blanketed by eolian bedforms. (c and d) Close-up on CTX (c) and interpretative sketch (d) showing a widening of the valley and a diversion into two branches to the South and to the East. Locally, the flow patterns reach $3 \mathrm{~km}$ in width, but do not display any incision into the bedrock. There, dark material (gray filling pointed by black arrows in d) display elongated features and are partly eroded (f). Q1 and Q2 are sections at which discharge rates have been estimated (Table 2). (e) Close-up on the diversion to the East showing elongated features interpreted as remnants of fluvial bars. ( $\mathrm{f}$ and $\mathrm{g}$ ) Close-ups on elongated ridges interpreted as a fluvial bars (HiRISE image PSP_007780_1985). The highest resolution shows that this material is covered by regularly spaced polygons of 10-20 m wide. 

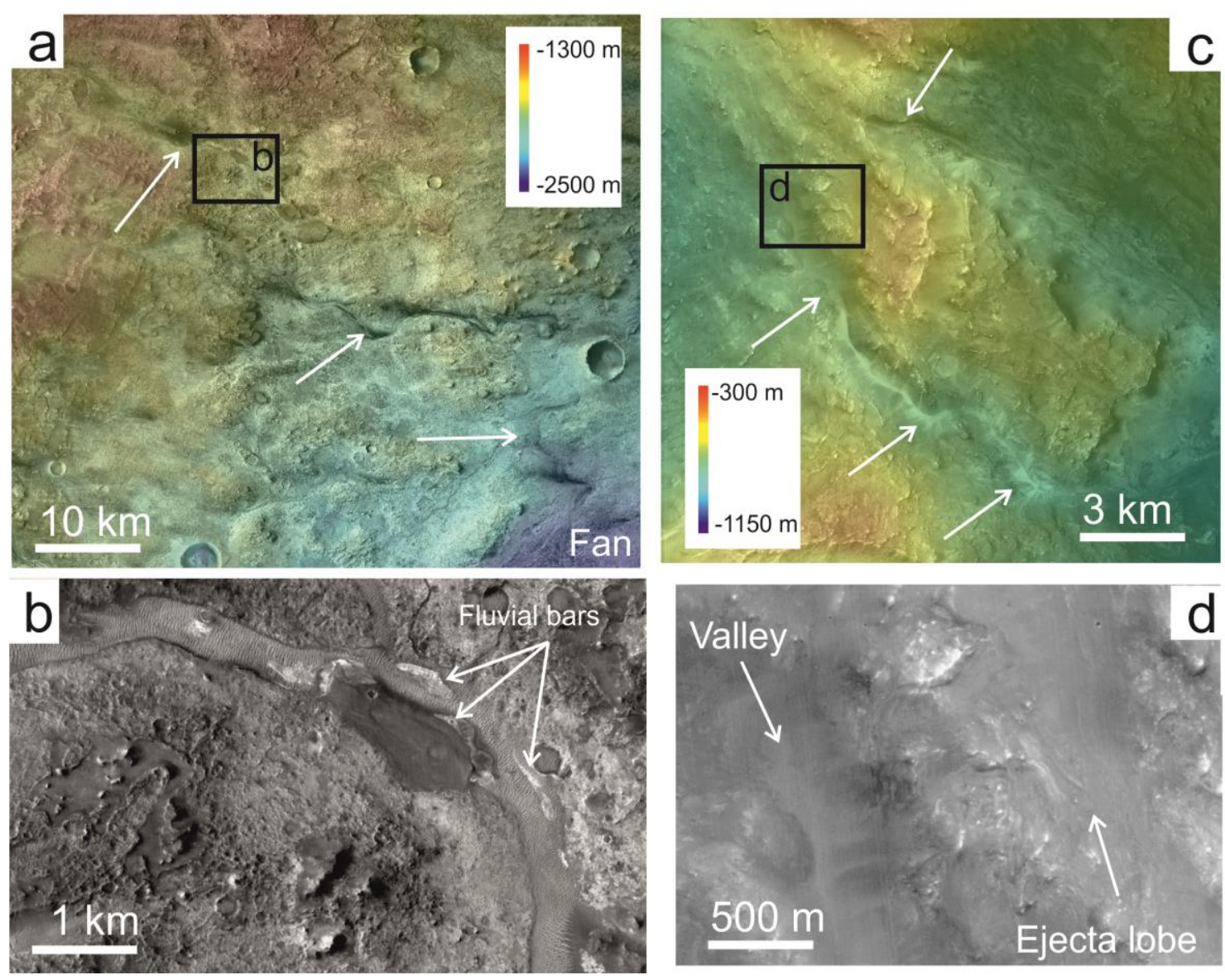

Figure 4: (a) Northern valley (CTX mosaic with color HRSC DEM in transparency). Flow from upper left to bottom right. The valley is not well visible in the topography. (b) Close-up on CTX image of the $500 \mathrm{~m}$ wide valley. The presence of fluvial bars (arrows) indicates flow features typical of channel deposits. (c) Close-up on two valley sections (white arrows) upstream of the northern valley without clear connection to the latter. (d) The basement is covered by Hargraves ejecta but the valleys are blanketed by smooth eolian material discarding obvious chronological relationships.

\subsection{Morphometry of fluvial valleys}

\subsubsection{Transverse topographic profiles}

Transverse topographic profiles help to quantify valley morphology (Figure 5). The upper portion of Neretva Vallis (westernmost $130 \mathrm{~km}$ ) is up to $4 \mathrm{~km}$ wide and presents deep incisions down to $400 \mathrm{~m}$ deep (Figure 5b and c, sections U1 to U6). Both, depth and width of the main tributary increase gradually downstream (similarly to canyons carving terrestrial plateaus), demonstrating an increase in supply related to incoming tributaries and extent in drainage area (e.g., Montgomery and Gran, 2001).

In contrast, the lower $70 \mathrm{~km}$ long portion of Neretva Vallis displays more subtle relief in the DEM. It shows shallow depths strictly limited to $50 \mathrm{~m}$, except at the entrance of Jezero crater where it 
incises the rim of the crater showing locally steep walls with a $300 \mathrm{~m}$ elevation difference at the rim intersection. The changes in width appear related to local variations in slope rather than a gradual increase in supply as would be the case with a number of tributaries increasing downstream. Indeed, no obvious tributary connects to Neretva Vallis in its last $70 \mathrm{~km}$.

This difference in depth between the upper and lower sections of Neretva Vallis is also highlighted by the difference in eroded volume. A total eroded volume of $56 \mathrm{~km}^{3}$ is calculated for the whole western valley system (in agreement with previous work, $58 \mathrm{~km}^{3}$, Fassett and Head, 2005) (Table 1). This volume takes into account only the valleys that are well defined in the topography, so it can underestimate the total eroded volume over the whole catchment. However, the upper valleys represent $95 \%$ of the volume $\left(53 \mathrm{~km}^{3}\right)$ while the lower valley accounts for only $5 \%\left(\sim 3 \mathrm{~km}^{3}\right)$ with large uncertainties $\left(\sim 1 \mathrm{~km}^{3}\right)$ that were difficult to estimate because of the lack of topographic signature in some locations. In addition, half of volume of the lower valley $\left(\sim 1.5 \mathrm{~km}^{3}\right)$ corresponds to the last $10 \mathrm{~km}$ at the breach into Jezero crater. Thus, the volume/length ratio of both portions of Neretva Vallis shows that the upper section has undergone $>10$ times more incision than the lower section, with a sharp transition from one to the other east of the basement plateau (East of U6 crosssection in Figure 5b).

\subsubsection{Longitudinal profiles}

Longitudinal profiles used here should be treated as a first-order-magnitude estimates for the main tributary given that those profiles follow a topography that has been modified by more recent processes (e.g., landslides, eolian activity). The longitudinal profile of Neretva Vallis displays a straight, slightly convex shape (Figure 5d). The edge of the basement plateau triggers a change in bedrock profile, which has strong implications for the erosion. In the upper section, Neretva Vallis becomes deeper as it gets closer to the edge of the plateau, as it has been observed from the transverse profiles (Figure 5c). The transition between the two types of valley style occurs near the location of a SW-NE fracture zone that also coincides with a difference in lithology between the pyroxene-bearing bedrock (west of the topographic step T) and the olivine-rich bedrock (East of T) (Figure 5a, 5d). Extensive degradation of the surface complicates the identification of the main valley at this location preventing a clear assessment of the transitions between the valleys incising the plateau and the channel-style valleys downstream.

Downstream, the channel-style valley is shallow compared to the surrounding bedrock and shows a straight longitudinal profile (Figure 5d). The topography of the basement in this area was difficult to follow because of its hilly and irregular texture. As a consequence, the difference in elevation between the plateau and the valley in the longitudinal profile between 130 and $180 \mathrm{~km}$ is irregular and imprecise because the surface has been modified by degradation processes unrelated to the fluvial erosion. The difference in elevation from the point $\mathrm{T}$ to the Jezero crater entrance is $\sim 500 \mathrm{~m}$ over a straight-line distance of $50 \mathrm{~km}(\sim 1 \%$ slope $)$, which is steeper than that of the plateau basement (from 0 to $1 \%$ ). Local slopes along the paleostreams are not significantly gentler in the lower section $(0.5$ to $0.8 \%)$ than in the upper section $(0.5$ to $1.3 \%)$. The two latter observations need to be taken into account in the understanding of the difference in style of the two parts of the valley (as discussed in section 4.1). 
Lastly, at the eastern edge of the profile, there is a $200 \mathrm{~m}$ elevation step at the entrance of Jezero crater, before reaching the lake deposits $(-2400 \mathrm{~m})$. At this location, the breach of the crater rim has created a deep valley. The difference of elevation along the valley floor is $200 \mathrm{~m}$ along the last 10 $\mathrm{km}$ (Figure 6), including a steep topographic step of $\sim 100 \mathrm{~m}$ over $1 \mathrm{~km}$ just before the fan deposits (Figure 6c, location $\mathrm{X}$ ).

\subsection{Fluvial regime and discharge rates}

No obvious channel is observed in the upper section of Neretva Vallis, precluding any calculation of hydrological parameters in this area of the watershed. The lower section is a location where an estimate of paleo-hydrology can be performed given the presence of channel landforms. Apparent channel widths vary from $200 \mathrm{~m}$ to $3 \mathrm{~km}$ in this lower section. Alluvial deposits are locally estimated to be a few tens of meters thick, at most. We estimated the discharge rates in three locations where the valley displayed channel features suggesting that the stream occupied the whole width of the valley, at Q1 and Q2 section (Figure 3c) and at the entrance of Jezero crater.

Among the three methods for discharge estimations, both Manning and Darcy-Weisbach require an estimation of the height of the channel. Using the apparent channel height is controversial because it is dues to a progressive incision rather than a single episode over its whole thickness. In addition, no HiRISE stereo images are available in key locations where the elongated landforms interpreted as fluvial bars are observed, those being too small for the HRSC DEM resolution. A $5 \mathrm{~m}$ high terrace was observed at the entrance into Jezero crater (Salese et al., 2019a) that can play as a local height for the entrance channel. For the other locations we base our estimations on empirical laws. It has been shown on Earth based on fluvial river datasets that the channel height $\mathrm{H}$ varies with the width $\mathrm{W}$ and the discharge rate $\mathrm{Q}: \mathrm{H}=0.33 \mathrm{Q}^{0.35}$ and $\mathrm{W}=3.67 \mathrm{Q}^{0.65}$ (Hey and Thorne, 1986, Knighton et al., 1998, both for small terrestrial rivers). This turns out to give: $\mathrm{H}=0.33(\mathrm{~W} / 3.67)^{0.78}$ at a given discharge rate. These empirical results can slightly vary with Mars gravity. According to Irwin et al. (2005), depending on the channel type, the height:width ratio can be down to 0.7 time the value it has on Earth because of the gravity difference. In order to provide conservative values we use these lowest bound to provide a channel height that is not overestimated in the three locations considered (rounded to the closest integer, results give $5 \mathrm{~m}$ at $200 \mathrm{~m}$ width and $10 \mathrm{~m}$ at $500 \mathrm{~m}$ width). These values are consistent with recent scaling relationships introduced by Konsoer et al. (2018) and with the value measured from a terrace at the channel entrance into Jezero crater by Salese et al. (2019), estimated to be $5 \mathrm{~m}$ depth for a width of $190 \mathrm{~m}$.

Discharge rates estimated at three locations along the lower section of the valley and at the entrance channel vary from 900 to $21,000 \mathrm{~m}^{3} . \mathrm{s}^{-1}$ by combining the extreme values of the three methods (Table 2). The comparison between the three methods gives a sense of the potentially large uncertainties related to these calculations. However, despite these large uncertainties, all methods point towards relatively high discharge rates $\left(10^{3}\right.$ to $\left.10^{4} \mathrm{~m}^{3} . \mathrm{s}^{-1}\right)$ in the three locations where these calculations have been made. These estimations of discharge rates are only valid for the last episodes of flow, possibly linked to the entrenchment of the depositional fan at its entrance (Figure 6). 

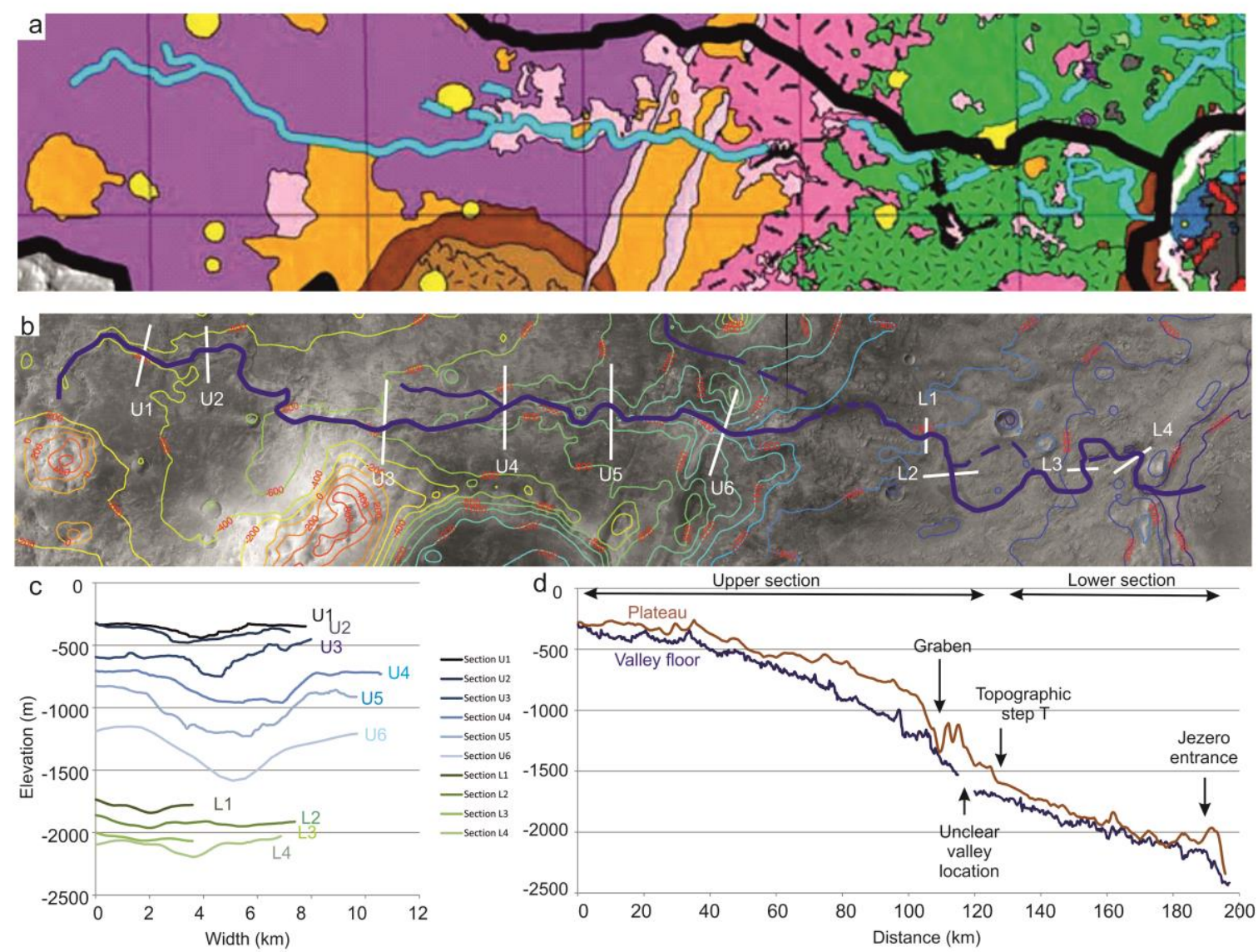

Figure 5: (a) Lithology map from Goudge et al. (2015). Green: Mottled terrain (olivine-bearing unit). Pink: Altered basement. Purple: Pitted capping unit. Orange: Dusty, massive basement. Brown: Crater rim material. (b) CTX mosaic with topographic contours in color (100 m spacing), main fluvial valley in blue and cross-section in white. (c) Transverse topographic profiles through the sections of valleys shown in (b) from U1 to U6 for the upper section and L1 to L4 for the lower section. (d) Longitudinal profiles of the main tributary (blue) and the surrounding plateau (brown). Note that the irregularities (local bumps) in the profiles are usually related to subsequent activities (small craters, fallen blocks, etc.) having modified the valley floor. 


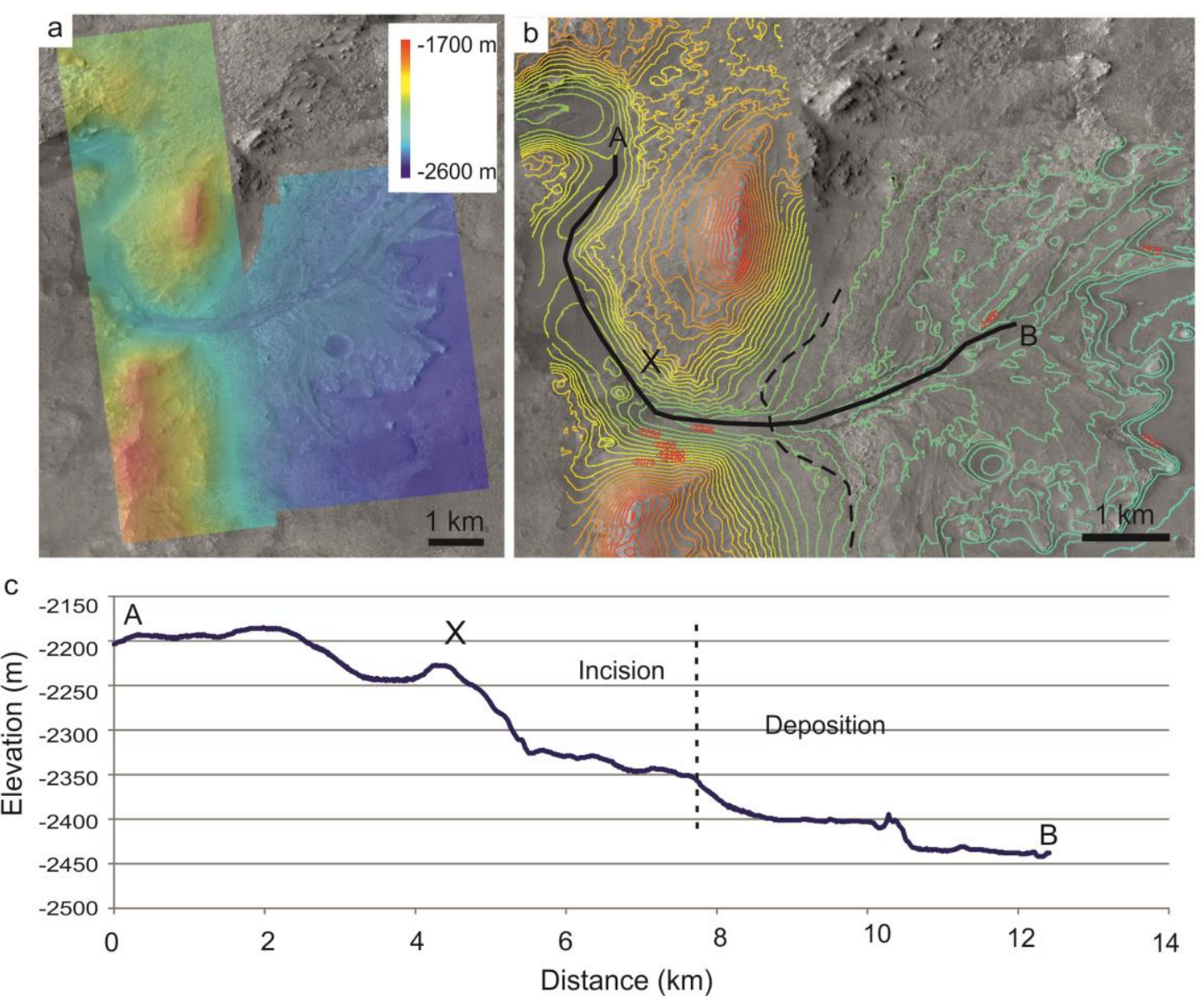

Figure 6: (a) Mosaic of CTX and HiRISE images with merged HiRISE DEMs in color (from west to east: ESP_036618_1985 and ESP_037119_1985, ESP_042315_1985 and ESP_037396_1985, PSP_002387_1985 and PSP_003798_1985) at the entrance of Jezero Crater. (b) Close-up of the entrance of Jezero Crater. The topography of the $12 \mathrm{~km}$ long transversal profile A-B is detailed in (c). The difference of elevation is of $200 \mathrm{~m}$ from A to the start of the depositional fan. The location $\mathrm{X}$ is a knickpoint with a steep slope of $10 \%$ (100 m of elevation in $1 \mathrm{~km}$ ) preceded by a local low linked to scouring before a resistant obstacle.

\subsection{Interpretations of geomorphological results}

\subsubsection{Interpretation of the longitudinal profiles}

Longitudinal valley profiles enable estimation of the degree of equilibrium of valleys, linked to their process of formation and potentially their duration of activity (e.g., Knighton et al., 1998, Charlton, 2007). Concave profiles are expected for river at equilibrium, although recent progresses on terrestrial works show that landscape evolution may not always lead to ultimately concave profile (e.g., Willett et al., 2018). Indeed, the longitudinal profile of a river profile depends on (1) the variations in discharge rate along the river, and, therefore, the number of incoming tributaries, (2) the base level (sea level on Earth, Jezero crater floor and lake), (3) the pre-existing topography and/or tectonic context and (4) the climatic conditions. For instance, on Earth, arid-zone streams have limited concavity or convex shapes due to the lack of tributaries downstream as well as the loss of water by evaporation and infiltration (Knighton et al., 1998, Willett et al., 2018). The topography used here is a first order estimation of the profile because a precise profile cannot follow 
the exact location of the past river (no channel visible in the upper part) and craters or landslides could have modified the shape locally. Keeping in mind these limitations, longitudinal profiles can inform us on the evolution of the valley system.

None of the investigated sections of the longitudinal profile for Neretva Vallis is concave. Profiles are either slightly convex or straight (Figure 5d). The slightly convex profile of the upper valley section can be explained by the presence of the topographic step at the edge of the plateau, which is progressively dissected (Figure 7a). This part of the longitudinal profile is linked to progressive backward erosion, either related to normal faults present at the eastern edge of the plateau that lowered down the base level progressively, or to the resistant lithology of the plateau, or both. An equilibrium (concave profile) was not reached likely because of the low number of tributaries and the substantial thickness $(400 \mathrm{~m})$ of plateau to erode.

This poorly dendritic network of deep valleys has some similarities in shape with valley networks such as Nanedi or Nirgal Valles, with tributaries showing amphitheater heads and steep valley walls. Steep valley heads with amphitheaters have been interpreted as sapping valleys in the past (e.g., Pieri et al., 1980, Laity and Malin, 1985, Malin and Carr, 1999), i.e., formed by deep subsurface flow, groundwater seepage and related erosion. Those valleys have been taken in the past as indicator of flows limited to the subsurface (e.g., Goldspiel \& Squyres, 2000), but it has been shown that recharges of aquifers from the surface are needed for such processes to occur and that overland flows are required both on Earth and Mars (Howard, 1986, Craddock et al., 2002, Irwin et al., 2008, Lamb et al., 2008; Mangold et al., 2008; Lapotre \& Lamb, 2018). Volcanic bedrock, especially basalts, has moderate porosity (10-30\%) but includes some of the most permeable formations on Earth (MacDonald et al., 1983, Davis and De Wiest, 1966, Gulick, 1998). According to Goudge et al. (2015) these valleys are carved within a basaltic capping unit, suggesting that groundwater may have been involved in combination with overland flows, as observed elsewhere on Mars (e.g., Salese et al., 2019b). However, although the valleys present a paucity of downstream tributaries, their longitudinal and transverse profiles show that the main tributary has neither amphitheater head nor constant valley width as usually observed for sapping, but rather a progressive incision into the plateau with gradual deepening and enlargement of the main tributary (Figure 5c) as observed for erosion dominated by overland flow. Lastly, the sinuous shape of the valley in the plateau is created by progressive incisions inherited from an initial state, possibly involving alluvial meandering channels (Johnson, 2016). Progressive incision by overland flows of an igneous basement certainly requires geologically long periods (>10,000 years), although estimations of durations are difficult and generally reported to be >100,000 for Mars valley networks (e.g. Gulick and Baker, 1990, Carr, 1995, Gulick, 2001, Howard et al., 2005).

In contrast, the very straight longitudinal profile of the lower section can be explained by the lack of tributaries: there is no downstream increase in stream power, thus similar erosional strength throughout the length of the valley without downward increase. Coupled with the low eroded volume and the presence of channel features, this straight profile is indicative of an immature valley, therefore distinct from the upper Neretva Vallis. The drop in elevation at the Jezero crater entrance (Figure 6) represents a change in base level that is interpreted as a knickpoint that did not propagate much backward, in agreement with the immature morphology of the lower valley section. Note that this drop in elevation does not correspond to the location where the river entered into the paleolake (-2395 m of elevation, Fassett and Head, 2005) and where sedimentary deposits start to accumulate. 
Between A and X (Fig. 6c), the longitudinal profile exhibits two small depressions that may be related to perched pools and/or local scouring of the bedrock, suggesting the flow at this location was energetic (i.e., as rapids), as expected for such a drop in topography on a short distance. Such a step is typical of knickpoints due to backward incision related to a change in the base level (e.g., Berlin and Anderson, 2009, Valla et al., 2010, Forster and Kelsey, 2012), here linked to the breach of Jezero crater rim.
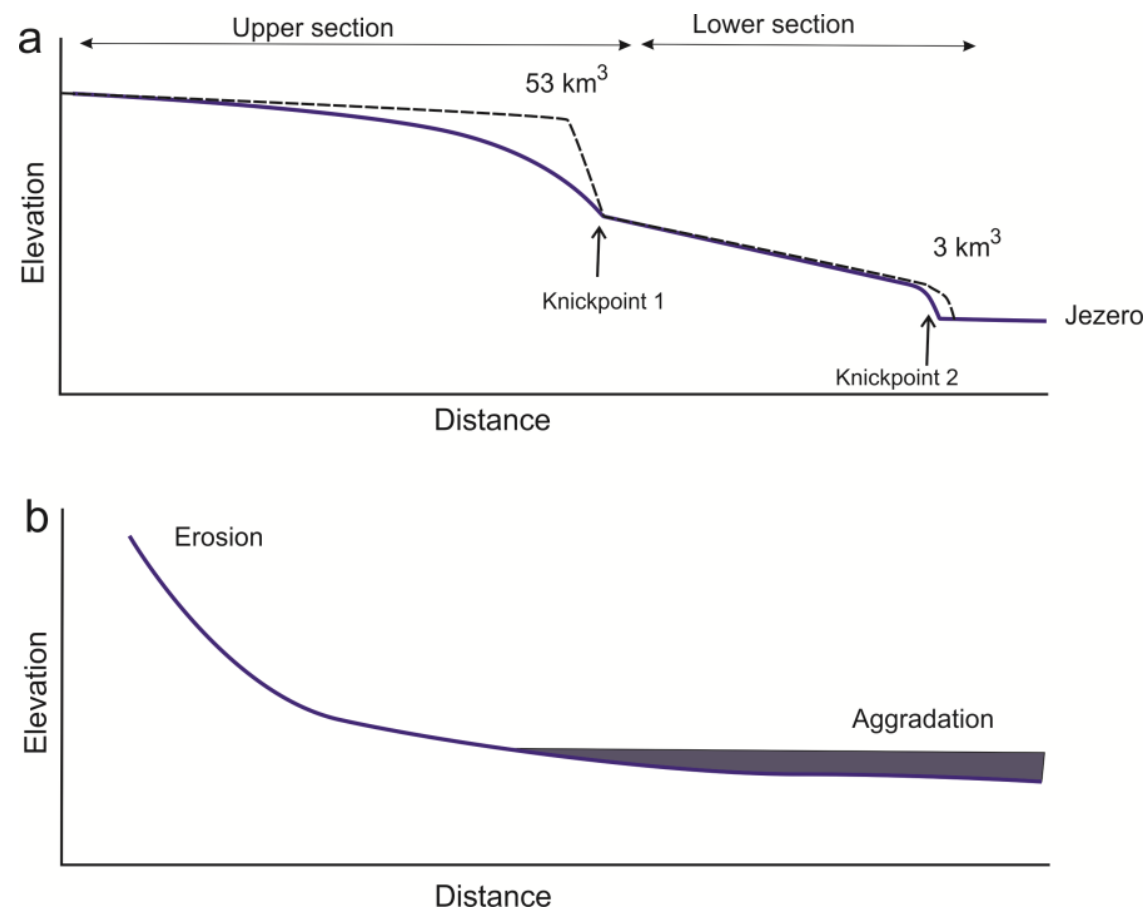

Figure 7: (a) Simplified sketch of the longitudinal profile of Neretva Vallis with the upper section incising into the basement and the lower section incising poorly into the olivine-rich unit and Jezero crater rim. The convex profile of the upper section is similar to a knickpoint controlled by normal faults and/or resistant lithology of the basement. The entrance into Jezero crater of the lower section corresponds to a knickpoint formed by the change in base level after the flow cut into the crater rims. (b) Ideal longitudinal profile of a long-term river with alluvial deposition at low gradient downstream (adapted from Charlton, 2007).

\subsubsection{Interpretation of the differences in morphology}

Morphological results highlight a strong difference in fluvial style between the channel-free, upper $130 \mathrm{~km}$ of Neretva Vallis that incises strongly into the basement and the tributary-free, channel-like morphology observed in the lower $70 \mathrm{~km}$ of Neretva Vallis and along the whole length of the northern valley. Two interpretations are possible at this stage: (A) the two styles formed coevally and the difference in morphology is related to the change in flow parameters (slopes, discharge rates, etc.) along the valley, or (B) the two regimes were not coeval, i.e., the western valley formed in two (or more) distinct episodes.

The longitudinal profile in Figure 5d is composed of two parts (as schematized on Figure 7a), with a lower straight section dominated by braided streams and alluvial deposits, characteristic of 
aggradation, distinct from the upstream section dominated by erosion. Such a profile is observed on Earth in the case of alluvial systems. For such a scenario (A) to be valid, the lower, aggradation section should correspond to flatter areas with significant sedimentary accumulation (alluvial plains) and should not display direct incision into the bedrock as observed upstream. Yet, local slopes along valleys in the western basin are not significantly gentler in the lower section $(0.5$ to $0.8 \%)$ than in the upper section $(0.5 \%$ to $1.3 \%)$. In addition, the lower section of Neretva Vallis incises into the olivine-rich bedrock (Figure 5b) without obvious alluvial deposits apart from the elongated deposits present inside the valley (Figure 3d), contrary to scenario (A).

Another question linked to alluvial deposition is related to where the eroded volume of the upper valleys $\left(53 \mathrm{~km}^{3}\right)$ has been deposited. It has been shown that many deltaic deposits on Mars follow a volume ratio of erosion to delta that is close to one, therefore suggesting single episodes and limited dispersion of sediments within the corresponding basins (Vaz et al., 2018). Thus, the volume eroded should fit the volume of deposited sediments in alluvial deposits and the fan delta. The darktoned deposits interpreted as fluvial bars and alluvial deposits in the lower valley represent $\ll<1 \mathrm{~km}^{3}$ of volume, far from the order of magnitude of the basement erosion and are thus not a significant sink. The observed depositional fan deposits within Jezero crater occupy a volume of $\sim 4-5 \mathrm{~km}^{3}$ depending on estimations (Fassett and Head, 2005, Table 1). This is much less than the total eroded volume as well. The eroded surface of the fan and residual buttes located in front of the fan may sign a former extension before its erosion by wind (Goudge et al., 2018). The volume of the eroded part of the fan has been estimated to $\sim 2.7 \mathrm{~km}^{3}$ in addition to its current volume (Goudge et al., 2018), thus totaling $7-8 \mathrm{~km}^{3}$ for its initial volume. This volume is still much insufficient to fill the gap of volume with that recorded by erosion, making Jezero crater an anomaly in the results reported by Vaz et al. (2018). Note that a change in volume from the erosional part to the deposition fan is possible based on terrestrial observations, but it is usually considered to increase the volume of deposits because the porosity of crustal rocks is lower than that of delta sediments before compaction (e.g., Reading, 1996), as would be the case of the poorly buried Jezero crater fans.

Further evidence against interpretation (A) comes from the presence of two knickpoints in the longitudinal profile. On one hand, the slightly convex topography upstream grabens can be compared to a knickpoint (knickpoint 1 in Figure 7) due to the backward propagation of the edge of the plateau progressively incised by fluvial erosion. On the other hand, the entrance in Jezero crater is characterized by a steep slope over $\sim 1 \mathrm{~km}$ (Figure 5d, knickpoint 2 on Figure 7a). Bedrock rivers have knickpoint migration rates ranging from 0.001 to $30 \mathrm{~m} / \mathrm{y}$, with a strong dependence on drainage areas (Loget and Van Den Driessche, 2009). In the Alps, knickpoints initiated at the same period in the same region have the same order of magnitude in backward incision (Valla et al., 2010). Valla et al. (2010) found that knickpoint retreat rates vary with drainage area first, while change in bedrock lithology is a secondary parameter. Thus, along a given river, knickpoints should display a higher step downstream (larger basin) than upstream (smaller basin), as the drainage area increases downstream. At least, it should be of the same order of magnitude downstream as upstream assuming constant supply due to lack of incoming tributaries in the lowermost part of the basin. Yet, the backward incision of the upper section is of ca. $80 \mathrm{~km}$ into the basement, while the backward incision observed at the Jezero entrance is of only $\sim 1 \mathrm{~km}$. In addition, the difference in estimated eroded volume is large $\left(53 \mathrm{~km}^{3}\right.$ vs $\left.3 \mathrm{~km}^{3}\right)$. The huge difference makes it unlikely that the same volume of water that transited into the upper section forming this strong incision would have transited through the observed breach of Jezero crater, or the knickpoint at this location would have 
migrated back much further. Thus, the comparison between the two knickpoints is consistent with a difference in fluvial regimes, with a longer duration of activity in the upper valley, as suggested by the longitudinal profiles.

These observations confirm the inconsistency in morphometry between the upper Neretva Vallis and the lower poorly developed channels, suggesting a distinct evolution as in interpretation (B). In this context, it may not be a coincidence that the difference in style between the strong valley incision to the west and the limited channel incision to the east starts at the transition between two lithologies (Figure 5). Indeed, the upper Neretva Vallis activity may have been active earlier than the lower valley section, implying that the fluvial bars and channel-type features observed downstream are not genetically linked to the same fluvial erosion that carved the canyons observed in the upstream section. Such an interpretation requires evaluating whether or not the change of lithology invoked could actually be responsible of a change in erosion style.

Rock strength is an important parameter that influences landscape erosion and fluvial incision (e.g. Bursztyn et al., 2015 The question raised is whether the change in lithology from the crustal basement and plateau cap rocks into the olivine bearing unit (Figure 5a) could constitute an explanation for the difference in morphology between the upstream and downstream parts of the valley. Assuming rock strength is the key parameter, the difference in eroded volume downstream would imply a higher strength of the olivine-bearing unit compared to the rocks of the basement. Yet, new studies interpret the olivine-bearing unit to be cemented ash deposits, especially based on the texture of this unit which appears to be weak, and based on the fact that it does not retain well small impact craters to erosion (Mandon et al., 2020). The moderate thermal inertia, the presence of yardangs and of a sparse regolith cover also indicate that the olivine-bearing unit is composed predominantly of friable clastic rocks (Bramble et al., 2017, Rogers et al., 2018, Kremer et al., 2019). So, this unit should be easier to erode by fluvial processes than the resistant basement upstream, contrary to what is deduced from the morphological analysis, thus confirming and enhancing the inconsistency between the two sections of the valley.

Lastly, interpretation (B) requires evaluating the relative ages of the landforms and bedrock units, given that, in such a scenario, the olivine-bearing unit should be younger than the cap rock basement and older than the delta fan. Next section will develop these questions on the age of the fluvial activity before to propose a complete scenario.

\section{Age of the fluvial system}

\subsection{Chronological relationships with surrounding landforms and geological units}

The plateau in the western part of the basin provided the topography for the formation of the upper Neretva Vallis; this Noachian plateau therefore predates the fluvial valleys. Neretva Vallis displays a change in style at the change in lithology at Nili Planum (Figure 1), between the Noachian basement and the olivine-rich unit (Figure 5). The olivine-rich unit clearly postdates the Noachian basement (Hoefen et al., 2000, Hamilton et al., 2005, Mustard et al., 2008) and appears to drape the pre-existing topography in a region roughly bounded by Nili Fossae to the west and Isidis basin to the east (Ehlmann and Mustard, 2012; Bramble et al., 2017, Kremer et al., 2019, Mandon et al., 2020). Its age remains unclear, although Middle to Late Noachian is the most likely (Mandon et al., 
2020.). Fluvial valleys cut the olivine-rich unit, but only those valleys that are poorly developed, braided, channel-like such as the lower section of the western valley and the northern valley. Inside Jezero crater, the fan-deltas can be compared to surrounding units. While the delta sits on the olivine-rich unit, confirming the observations from previous observation, the floor unit appears to postdate the fan-delta (Goudge et al., 2015). The impact craters superposed on this floor unit give a model age of $2.6 \pm 0.5 \mathrm{Ga}$ in the Hartmann system, placing it in the Early Amazonian (Shahrzad et al., 2019), thus providing an upper bound for the age of the delta deposition.

Crosscutting relationships with impact craters can also provide useful information. Jezero crater is interpreted to be Noachian in age (Ehlmann et al., 2009, Goudge et al., 2015), in accordance with its degraded morphology and the lack of obvious ejecta typical of craters of that period (Mangold et al., 2012a). However, the crater itself provides little information about the age of the fluvial activity. In contrast, the ejecta of the Hargraves crater (NW of the area of interest, Figure 1) drapes part of the Early Hesperian lavas of Syrtis Major Planum in Nili Fossae (Mangold et al., 2007, Mustard et al., 2009), providing an Early Hesperian maximum age for the crater formation. Thus, Hargraves ejecta blanket represents an important stratigraphic marker. According to Goudge et al. (2015), the Jezero inlet valleys are Noachian and pre-date Hargraves crater formation. However, there is no indication that any valleys are buried by Hargraves ejecta, neither for the western nor for the northern system. In contrast, small fluvial valleys cut its ejecta (SV in Figure 1). The relationship between the ejecta and the main valley systems remains unclear, due to the strong etching of the bedrock, and it is not possible to conclude definitively whether those small valleys are coeval to Neretva Vallis or not. Nevertheless, small fluvial valleys observed inside Hargraves ejecta point toward the occurrence of some post-Noachian fluvial activity that post-dated the Hargraves impact.

Considering relationships with tectonic features, the valleys postdate the SW-NE system of grabens that cut into the Noachian basement, but not into Syrtis Major Hesperian plains. Nevertheless, those grabens are deep (down to $300 \mathrm{~m}$ ) and have not deflected the valleys toward SW or NE directions, or any deflection is no longer visible (Figure 1). A coeval evolution of grabens and valleys is also possible.

\subsection{Age of the fluvial activity from crater counts}

Crater-count techniques are commonly used for dating surface of a given age such as well-defined volcanic plains (e.g., Hartmann and Neukum, 2001). Dating linear features such as fluvial valleys cannot be performed exactly the same way. Buffered crater counts are most commonly used to date linear features because they take into account the fact that the surface area over which the count should be performed is a function of crater diameter (e.g., Tanaka, 1982). Fassett and Head (2008) have used this technique by considering the area around the valley segments inside valley networks, assuming that all valleys of a given network are coeval. For the basin upstream of Jezero crater, they found a Late Noachian age (3.74 \pm 0.14 Gy following the Hartmann chronology). However, this technique is powerful for dense, widespread valley networks, but statistically limited for networks with few tributaries. Only 7 craters of more than $2 \mathrm{~km}$ were counted for Jezero basin, including Hargraves crater. Yet, Hargraves crater is Hesperian with unclear relationships with the inlet valleys entering into Jezero crater, so should not be included in such a count. In addition, its large diameter $(60 \mathrm{~km})$ makes a strong load on the estimation, questioning the validity of the age found. Given the limited basin area and valley number, we choose not to reproduce such a buffered count. 
In order to still provide a crater count age for the fluvial activity, we chose to perform a crater count of the western fan-delta. Several craters are observed on the top of the main remnant delta fans of Jezero crater or affecting its edge (Figure 8). The size frequency distribution of the craters shows that craters larger than $250 \mathrm{~m}$ follow isochrons quite well, while the distribution of the craters smaller than $250 \mathrm{~m}$ do not follow any of the isochrons. To estimate the age of the surface, we can use the 10 craters larger than $250 \mathrm{~m}$, which post-dates the fan-delta (Figure 8). Despite the low statistical sampling, these 10 craters align along the $3.5 \mathrm{~Gy}$ isochron, with some error bars related to the low statistical sampling giving possible ages from 3.2 to $3.6 \mathrm{~Gy}$, thus leading to a Hesperian age. The 3.2 Gy lower bound can be used as a minimum age in agreement with the crater counts that were done on the postdating floor unit that returns an age of 2.6 $\pm 0.5 \mathrm{~Gy}$ (Shahrzad et al., 2019). The craters lower than $250 \mathrm{~m}$ with a distribution lower than the isochrons imply continuous crater obliteration/degradation (e.g. Quantin-Nataf et al., 2019). This is consistent with the partly eroded texture of the fan-delta surface, likely connected to the aeolian erosion over $>3 \mathrm{~Gy}$. While only the craters smaller than $250 \mathrm{~m}$ have been clearly affected by this degradation, we cannot rule out that some erosion may have affected the cratering record of craters larger than $250 \mathrm{~m}$ as well, leading to an underestimation of the model age, thus opening the possibility to slightly older ages than the 3.6 Gy upper bound provided by the crater count.

In summary, from crosscutting relationships, the formation of the fan-deltas, thus of the last phase of the Jezero fluvial activity, postdates the formation of the olivine-rich unit (MN-LN) and predates the formation of the floor unit (EA). From crater counts, an Early or Late Hesperian age $(3.5+0.1 /-$ $0.3 \mathrm{~Gy}$ ) is favored, ruling Amazonian ages, but a Late Noachian age is still possible assuming missing craters related to a surface degradation of the fan-delta. Thus, from crater counts and crosscutting relationships, we cannot conclude definitively about the age of the fan-delta formation, leaving open a Late Noachian or Hesperian age of formation.
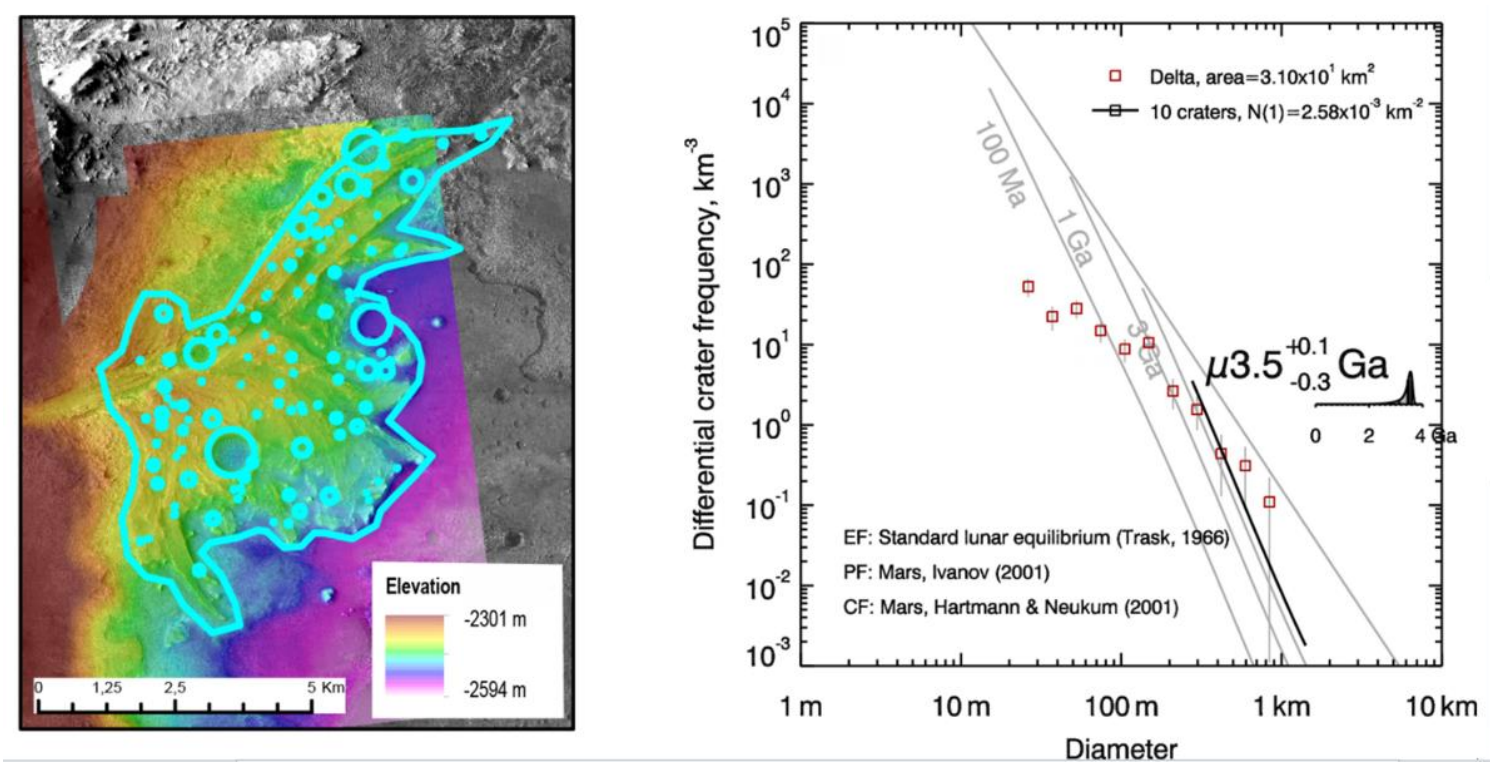

Figure 8: (left) CTX DEM (J03_045994_1986 and J03_046060_1986_XN_18N282W) over HiRISE image mosaic on top of which the counted area and the mapped craters are highlighted in light blue. (right) Crater size frequency distribution obtained from the craterstat software (Michael and Neukum, 2010). PF is production function, CF is crater frequency, and EF is equilibrium function. The age is the best fit for the 10 craters larger than $250 \mathrm{~m}$. 


\section{Discussion}

\subsection{Scenario and period offormation of fluvial landforms}

Neretva Vallis is divided in an upper section (130 km long) with significant fluvial activity inferred from the presence of deep canyons cutting into the basement plateau, and a lower section $(70 \mathrm{~km}$ long) with much lower eroded volume and immature valley development. Quantitative parameters do not plead in favor of a common evolution of the two fluvial styles. Formation of the olivine-rich unit between the two episodes of valley formation would explain why the level of erosion observed upstream is not observed on the downstream section. We present a scenario that takes into account these observations and interpretations (Figure 9):

(1) The basement is subjected to relatively intense erosion $\left(53 \mathrm{~km}^{3}\right.$ at minimum) from precipitation (rainfall and/or snow deposition and melting) with development of deep valley networks (>100 m deep). Sediments eroded by this fluvial activity were deposited downward in two possible locations, either in topographic lows west of Jezero, or inside Jezero crater, which is a regional low area and was already present at that period.

(2) The olivine-rich unit blanketed the eastern part of the valley network, as well as sediments deposits during the first phase of fluvial activity, and the interior and rim of Jezero crater, at least partly, burying any former fluvial and lacustrine deposits deposited in this area.

(3) The valley system was reactivated, either in continuity of the previous phase, or, independently and later, forming the lower western valley (Neretva Vallis) and the northern valley at the same time. The observed fan-deltas formed as a result of this second stage of activity.

According to this scenario, the fluvial activity carving the upper valley would have started before the olivine-rich unit was emplaced, thus likely during the Middle Noachian. Morphologically, the upper Neretva Vallis fit the valleys formed in the Middle to Late Noachian on volcanic plateaus (e.g., Howard et al., 2002, Fassett and Head, 2008). It displays a drainage density of $\sim 0.05 \mathrm{~km}^{-1}$, which is common in martian highlands (Carr and Chuang, 1997). The Strahler order of 3 is relatively low, compared to 4 or 5 in densely incised martian highlands (Ansan et al., 2013), but reasons for the low degree of branching of valleys and moderate density can be related to various parameters such as permeable bedrock, precipitation concentrated on one region of the basin or local groundwater seepage, or a combination (e.g. Knighton, 1998). In absence of inner channels a reconstitution of the paleohydrology and the duration of erosion is not possible. Based on Earth and Mars studies the minimum duration of well-developed valley networks formation is usually considered to be in the range of 0.1 to $10 \mathrm{My}$ (e.g., Carr, 1995, Gulick, 2001, Howard et al., 2005).

In contrast, the ages of the lower valley section of Neretva Vallis and of the northern valley, remain unconstrained, Late Noachian or Hesperian. These uncertainties require looking at other fluvial landforms in this region and on the whole planet for a better understanding of their period of formation. The pristine fluvial landforms of the lower and northern valleys do not share similarities with Noachian valleys observed elsewhere on Mars. Channels in well-developed fluvial Noachian valleys on Mars are locally visible on the floor of valleys (e.g., Irwin et al., 2005), but they are substantially narrower and shallower (>10 times) than the valleys in which they are observed, as expected for fluvial erosion. The fluvial landforms are relatively fresh-looking, and have similarities 
with small outflow channels (e.g., Carr, 1987, Baker et al., 1992) or late-stage fluvial landforms. For instance, fluvial bars and braided streams are observed in the Late Hesperian outflow channel Okavango Valles (Mangold and Howard, 2013) or in Amazonian braided streams (Adeli et al., 2016). Apparent local discontinuity in flows also exist on valleys of the NE rim of the Hellas basin where a series of small valleys named Navua Valles (Hargitai et al. 2017, 2018, 2019) resemble in geometry (local braiding and avulsions, poor branching) and size (tens of km long) the lower western valley and the northern valley at Jezero crater.Navua Valles channel and valley systems have been interpreted as due to periodic fluvial episodes resulting from localized orographic highland precipitation and from snowmelt or hydrothermal groundwater outflow from volcanic and impact crater sources extending from the Noachian to the Amazonian (Hargitai et al., 2017, 2018, 2019).

Reactivation of Noachian valleys is not a new observation as it has been observed in Viking images (Baker and Partridge, 1986). Hesperian or Amazonian fluvial episodes on Mars have been observed in several locations and display valleys similar to channels, as suggested here for the lower sections. Although lower in intensity than the Late Noachian fluvial stage, these late-stage episodes represent significant fluvial erosion (e.g., Kite et al., 2019). Many depositional fans of the same range of size as Jezero crater are known to be Hesperian in age, for instance at Eberswalde crater (Mangold et al., 2012b), in Valles Marineris area (Quantin et al., 2005, Di Achille et al., 2007) or in Xanthe Terra (Hauber et al., 2009). Regionally, the presence of an alluvial fan inside the Hesperian crater Hargraves (Mangold et al., 2007, Goudge et al., 2015), small valleys cutting the Hargraves ejecta (Figure 1), and braided channels in the surrounding of the Hesperian Syrtis Major lava flows (Mangold et al., 2008), shows that the fluvial activity in this region extended well into the Hesperian period.

The origin of late-stage fluvial activity remains debated: climatic episodes including snowmelt and glacial melting perhaps related to obliquity variations (e.g., Kite et al., 2017), punctual volcanic activity (e.g., Gulick and Baker, 1990, Gulick, 1998, 2001, Hauber et al., 2005) or impact craters (e.g., Segura et al., 2008, Jones et al., 2010, Mangold, 2012) can generate episodic activities. The crater Hargraves is large enough to have generated melting of any subsurface ice, and Syrtis Major volcanism could have created a regional source of heat for melting of ice (Hiesinger et al., 2004). However, there is no direct evidence for the role of glacial ice, permafrost melting or snowmelt in the upstream regions. So, a late-stage aqueous episode forming the depositional fans at Jezero crater would remain of unclear origin.

Lastly, data from channel widths and discharge rates can be used to estimate the minimum duration of the fluvial activity related to the last phase of activity. As an example, from the fan volume, we can estimate a minimum duration taken to transport the $\sim 4-5 \mathrm{~km}^{3}$ of sediments of the fan, assuming continuous filling and a given water:rock ratio (W:R). The duration of 4 years is obtained using a $\mathrm{W}: \mathrm{R}$ of 50, which is a realistic ratio in moderately concentrated flows. This duration is consistent with the $\sim 11$ years proposed by Fassett and Head (2005), using their discharge rate estimations on the fan, and the 20-40 years of Schon et al. (2012) based on scroll bar migration. More in-depth modeling of the discharge rates using the channels at the entrance of Jezero crater has been done by Salese et al. (2019a). Results give durations of the hydrological activity leading to the formation of the fan-delta in hundreds of years (90-550 years) with varying parameters. Even this duration is still a minimum given the possible intermittency in floods; it corresponds to the overall time of the 
hydrological activity needed to form such delta fans, thus has important implications for climatic constraints. This relatively short duration at geological scale is consistent with the possible duration of late-stage fluvial episodes observed throughout the planet (Kite et al., 2019 and references therein) but it does not rule out the possibility that Jezero fan-delta formations correspond to the last gasp of the Late Noachian optimum.

1. Noachian fluvial erosion and putative sedimentary sinks

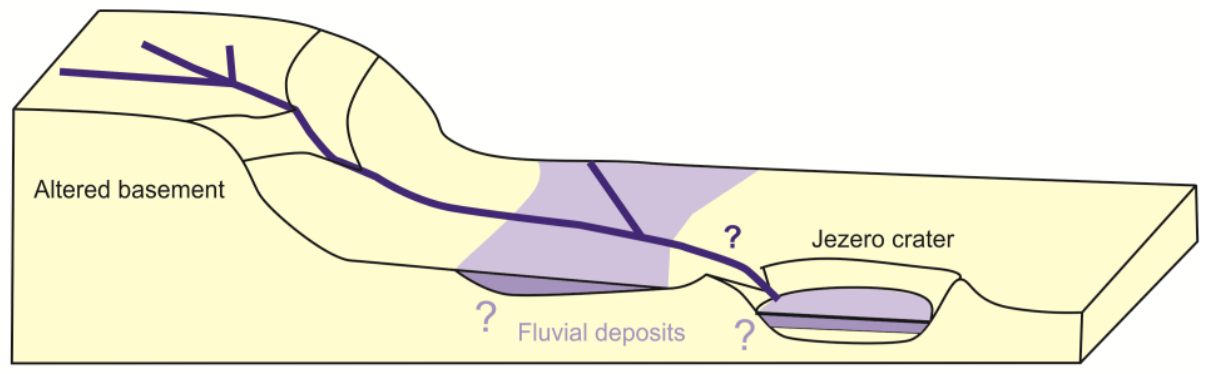

2. Late-stage fluvial erosion and deposition in Jezero crater

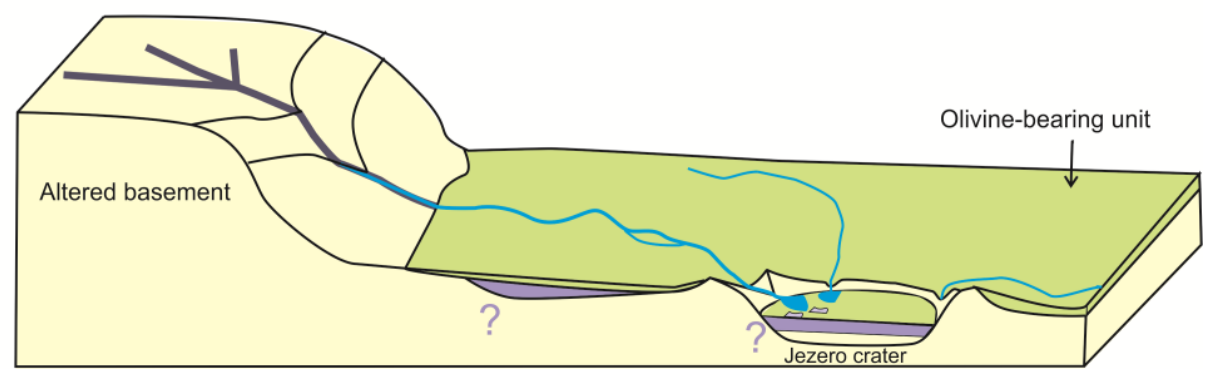

Figure 9: Scenario of the two-stage formation of Jezero crater fluvial activity. (a) Prolonged erosion of the basement during the Noachian period. Deposits from this period would have accumulated inside foothills or inside Jezero crater through an initial breach into rims. (b) Reactivation of the fluvial system after the formation of the olivine-rich unit with formation of the depositional fans.

\subsection{Implications of Jezero crater as a landing site for the Mars 2020 Perseverance rover}

This study highlights several important conclusions relevant to Mars 2020's exploration and future sampling of deposits within Jezero crater. The observed late-stage episode, potentially Hesperian, and the high discharge rates of the channels immediately upstream the main fan-delta question the exobiological relevance of Jezero crater regards to Early Mars climate. A late-stage, short duration lake could have been permissive of the incipience and development of any microbial life. The same argument might be poised against the probability that the subaqueous deposits that are the most accessible by the rover may be dominated by Hesperian sedimentary rocks, and thus are potentially less relevant to exobiological studies than those formed earlier (McLennan et al., 2011). Indeed, the specific evolution of Mars as a planet suggests that the best time interval for the search for biosignatures would be represented by early to mid-Noachian rocks, when clays were thought to be forming (Summons et al., 2011). However, aqueous activity existed a while prior to this ultimate episode, and may have already started a biologically active environments, incorporated and fossilized in-situ organics.

Besides the general favorable sedimentary context, the western Jezero fan sediments contain phyllosilicates in the form of iron-magnesium smectite clays and carbonates (Ehlmann et al., 2008). 
Abundant observational and experimental data show that many phyllosilicates, particularly smectites, are capably of preserving organic material due to strong absorption capacity, low reactivity, and low permeability when compacted (Farmer and Des Marais, 1999; Meyers and Ishiwatari, 1995). As a sedimentary sink, Jezero crater lake represents a terminal receptor for both primary and transported organics, and Jezero crater clay-bearing deposits appear to be very appropriate biosignature repositories. The catchment west of Jezero crater includes a broad area with a diversity of volcanic-related rocks, including many locations with alteration minerals that have been interpreted to be of hydrothermal origin (e.g., Mangold et al., 2007, Mustard et al., 2009, Goudge et al., 2015). These locations could have been favorable to biological activity prior to the fan formation. Whatever the duration and age of the fan-delta, the layers at the bottom of the fan deposits (bottomsets) would have concentrated fine-grained materials favorable for organic materials, especially inside phyllosilicates that are favorable to their preservation.

In terms of depositional environment, the high channel discharges estimated, at least for the latest stages of activity, imply that deposits would be dominated by coarse-grained clastic deposits (coarse sandstones, conglomerates) without a good potential for biosignature preservation. Nevertheless, ancient organic molecules will be preserved only if buried in sediments, and long-term preservation will occur only if buried organics are shielded from oxidizing fluids. The most beneficial influence of the limited-in-time, late depositional activity at Jezero crater certainly lies in the possibility that any potential organic matter, "pelagic" or transported in the Jezero crater, was probably buried rapidly, impeding chemical dissociation and thermal alteration of the organic molecules. Thus, one of the implications for exobiology of this study is that there may be a higher probability to find organics inside the Jezero crater sedimentary deposits that would have collected and concentrated previously formed organics in the finest-grain deposits (such as in bottomsets) rather than expecting organics formed during Jezero paleolake activity (with poor concentration expected), or organics preserved inside the coarser-grained locations of the delta deposits (topsets and inverted channels).

Lastly, several aspects of our work are testable from in-situ or sample returned data. The sampling of the grain size of fluvial channels of the delta would enable to reassess the calculation made in Salese et al. (2019a), and thus, improve the estimations made for the paleolake activity duration. Another benefit of the coarse detrital component would be that the fan-delta would play as a sampling bag of most types of bedrock present upstream, in a widespread basin, including olivine/carbonate-rich rocks and clay-bearing altered basement (as discussed by Goudge et al., 2015 and 2018), thus potentially enabling the identification of source rocks in-situ. Samples returned from coarse sedimentary rocks could enable determination of their age and magmatic origin.

\section{Conclusions}

The morphometry of the fluvial valleys leading to Jezero crater was studied to better understand the context and timing of the fluvial activity that led to the formation of the Jezero paleolake and depositional fans that were initially described by Fassett and Head (2005). Two fluvial valleys enter Jezero crater, to its west (Neretva Vallis) and north, both forming depositional fans. Neretva Vallis is divisible into an upper section (130 km long) with significant erosion observed from the deep canyons (down to $400 \mathrm{~m}, 4 \mathrm{~km}$ wide) cutting into the basement plateau (53 $\mathrm{km}^{3}$ of erosion), and a lower section ( $70 \mathrm{~km}$ long) with less erosion $\left(<3 \mathrm{~km}^{3}\right)$ and immature valley development, pointing 
towards a different erosional style and a distinct period of activity. The longitudinal and transversal topographic profiles of the western valley show that the degree of erosion reached in the upper part cannot account for the topography observed in the lower section and at the entrance into Jezero crater. Our interpretation of these differences is that the main fluvial erosion occurred before the olivine-rich unit draping part of this region was deposited, and that a subsequent fluvial episode explains the lower valley morphometry, which is directly linked to the fan-delta inside Jezero crater.

Crosscutting relationships and crater counts on the fan-delta enabled to constrain this episode to the Late Noachian or Hesperian. However, while the deep upper valleys are consistent with typical Noachian fluvial activity on Mars, the lower valley morphology present pristine channel landforms, high channel discharge rates, and a relatively short duration of formation of the main depositional fan (Salese et al., 2019a), which are characteristics typically observed for late-stage processes (deltaic deposits, alluvial fans, Kite et al., 2017). An Hesperian age should therefore be considered as a serious alternative to a Noachian age for the Jezero fan-deltas formation. In contrast, crater counts conclude for an age strictly older than 3.2 Gy, thus discarding an Amazonian age for the fandelta formation.

Considering the favorable depositional environment and mineralogy it affords, the western Jezero fan has retained much credence to ensure a substantial potential for preserving biosignatures, and maximize the science return from the robotic payload and samples. However, risks exist regarding the timing and duration of the paleolake activity, potentially postdating the optimum of fluvial activity and aqueous alteration on Mars in the Noachian. One of the implications for exobiology of this study is that there may be a higher probability of finding organics inside the Jezero crater sedimentary deposits that would have collected and concentrated previously formed organics in the finest-grain deposits (such as in bottomsets) rather than expecting organics formed during Jezero paleolake activity or organics preserved inside the coarser-grained locations of the delta deposits (topsets and inverted channels). Ground truth by the Perseverance rover will provide key information to validate or invalidate some of the interpretations made in this study. Nevertheless, our results should be taken into account to conduct a realistic set of analyses by the rover, as well as in the selection of samples of interest for a future mission of sample return (iMOST, 2019).

\section{Acknowledgments}

We thank G. Gulick, S. Holo and M. Lapôtre for their insightful comments. We acknowledge discussions within the Mars 2020 Perseverance rover Science Team. The data (HRSC, CTX, HiRISE, MOLA) that support the findings of this study were obtained freely from the Planetary Data System (PDS) and are publicly available online at https://pds.nasa.gov/index.shtml. The authors wish to thank MRO and HRSC team for these data. French authors are supported by the CNES (Centre National d'Etudes Spatiales) and Francesco Salese is supported by Marie Curie Individual Postdoctoral Fellowship (WET_MARS, Grant Agreement No. 795192). 


\section{References:}

Adeli, S., Hauber, E., Kleinhans, M., Le Deit, L., Platz, T., Fawdon, P., Jaumann, R. (2016) Amazonian-aged fluvial system and associated ice-related features in Terra Cimmeria, Mars. Icarus 277:286-299.

Amidon, W. H., and Clark, A. C. (2015) Interaction of outburst floods with basaltic aquifers on the Snake River Plain: Implications for Martian canyons. Geological Society of America Bulletin 127(5-6):688-701. https://doi.org/10.1130/B31141.1

Ansan V., Loizeau, D., Mangold, N., Le Mouélic, S., Carter, J., Poulet, F., Dromart, G., Lucas, A., Bibring, J.-P., Gendrin, A., Gondet, B., Langevin, Y., Masson, Ph., Murchie, S., Mustard J. F. and Neukum, G. (2011) Stratigraphy, mineralogy, and origin of layered deposits inside Terby crater, Mars. Icarus, 211:273-304 doi:10.1016/j.icarus.2010.09.011.

Ansan, V. and Mangold, N. (2013) 3D Morphometry of valley networks on Mars from HRSC/MEX DEMs: Implications for climatic evolution through time. J. Geophys. Res. 118:1-22, DOI10.1002/jgre.20117

Baker, V.R. and Partridge, J.B. (1986) Small Martian valleys - pristine and degraded morphology. Journal of Geophysical Research 91(B3) :3561-3572.

Baker, V.R., Carr, M.H., Gulick, V.C., Williams, C.R., Marley, M.S. (1992) Channels and valley networks. In: Kieffer, H.H. et al. (Eds.), Misc. Univ. of Ariz. Press, Tucson, pp.493-522.

Berlin, M. M. and Anderson, R. S. (2007) Modeling of knickpoint retreat on the Roan Plateau, western Colorado. J. Geophys. Res. 112:F03S06, doi:10.1029/2006JF000553.

Berlin, M. M., and R. S. Anderson (2009) Steepened channels upstream of knickpoints: Controls on relict landscape response. J. Geophys. Res. 114:F03018, doi:10.1029/2008JF001148.

Bramble, M. S., Mustard, J. F., and Salvatore M. R. (2017) The geological history of Northeast Syrtis Major, Mars. Icarus, 293:66-93.

Bursztyn, N., J. L. Pederson, C. Tressler, R. D. Mackley, K. J. Mitchell (2015). Rock strength along a fluvial transect of the Colorado Plateau - quantifying a fundamental control on geomorphology, Earth Planet. Sci. Let., 429, 90-100.

Carr, M. H. (1987) Water on Mars. Nature, 326:30-35.

Carr, M. H. and F. Chuang (1997) Martian drainage densities. J. Geophys. Res.-Planets 102:91459152.

Carter, J., Poulet, F., Bibring, J.-P., Mangold, N., and Murchie S. L. (2013) Hydrous minerals on Mars as seen by the CRISM and OMEGA imaging spectrometers: Updated global view. J. Geophys. Res. Planets, 118:831-858, doi:10.1029/2012JE004145. 
Charlton, R. (2007) Fundamentals of Fluvial Geomorphology. Taylor \& Francis, 280 pp.

Craddock, R. A., and Howard, A. D. (2002) The case for rainfall on a warm, wet early Mars. $J$. Geophys. Res. 107(E11):5111, doi:10.1029/2001JE001505.

Davis, S.N. and R.J.M. DeWiest, Hydrogeology, John Wiley, New York, 1966.

Dehouck, E., Mangold, N., Le Mouelic, S., Ansan, V., and Poulet, F. (2010) Ismenius Cavus, Mars: A deep paleolake with phyllosilicate deposits. Planet. Space Sci. 58:941-946, doi:10.1016/j.pss.2010.02.005.

Di Achille, G., and Hynek, B. M. (2010) Deltas and valley networks on Mars: implications for a global hydrosphere. In: Cabrol, N.A., Grin, E.A. (Eds.), Lakes on Mars. Elsevier, Oxford, UK, pp.223-248.

Di Achille, G., Ori, G.G., and Reiss, D. (2007) Evidence for late Hesperian lacustrine activity in Shalbatana Vallis, Mars. J. Geophys. Res. 112 :E07007, doi:10.1029/2006JE002858.

DiBiase, R.A., Limaye, A.B., Scheingross, J.S., Fischer, W.W., and Lamb, M.P. (2013) Deltaic deposits at Aeolis Dorsa: sedimentary evidence for a standing body of water on the northern plains of Mars. J. Geophys. Res.118:1285-1302. http://dx.doi.org/10.1002/jgre.20100.

Ehlmann, B.L., Mustard, J. F., Fassett, C. I., Schon, S. C., Head III, J. W., Des Marais, D. J., Grant, J. A. and Murchie, S. L. (2008a) Clay minerals in delta deposits and organic preservation potential on Mars. Nat. Geosci. 1:355-358. http://dx.doi.org/10.1038/ngeo207.

Ehlmann, B.L., Mustard J. F., Murchie S. L., Poulet F., Bishop J. L., Brown A. J., Calvin W. M., Clark R. N., Des Marais D. J., Milliken R. E., Roach L. H., Roush, T. L., Swayze G. A., Wray J J. (2008b) Orbital identification of carbonate-bearing rocks on Mars. Science 322 :1828-1832. http://dx.doi.org/10.1126/science.1164759.

Ehlmann, B.L., et al. (2009) Identification of hydrated silicate minerals on Mars using MROCRISM: geologic context near Nili Fossae and implications for aqueous al-teration. J. Geophys. Res.114, E00D08. http://dx.doi.org/10.1029/2009JE003339.

Ehlmann, B. L. and Mustard J. F. (2012) An in-situ record of major environmental transitions on early Mars at North Syrtis Major. Geophys. Res. Let., 39, L11202.

El Maarry, M. R., J. Kodikara, S. Wijessoriya, W. J. Markiewicz, and N. Thomas (2012), Desiccation mechanism for formation of giant polygons on Earth and intermediate-sized polygons on Mars: Results from a pre-fracture model, Earth \& Planet. Sci. Lett., 323, 19- 26.

Farmer, J. D., Des Marais, D.J. (1999) Exploring for a record of ancient Martian life, Journal of Geophysical Research 104, 977-995. 
Fassett, C.I., and Head, J.W. (2005) Fluvial sedimentary deposits on Mars: ancient deltas in a crater lake in the Nili Fossae region. Geophys. Res. Lett. 32:L14201. http://dx.doi.org/10.1029/2005GL023456.

Fassett, C.I., and Head, J.W. (2008) The timing of martian valley network activity: con-straints from buffered crater counting. Icarus 195:61-89. http://dx.doi.org/10.1016/j.icarus.2007.12.009.

Fassett, C. I., and Head III J. W. (2008a) The timing of Martian valley network activity: Constraints from buffered crater counting. Icarus, 195:61-89, doi:10.1016/j.icarus.2007.12.009.

Fassett, C. I., and Head J. W. (2008b) Valley network-fed, open-basin lakes on Mars: Distribution and implications for Noachian surface and subsurface hydrology. Icarus, 198:37-56, doi:10.1016/j.icarus.2008.06.016.

Forster, M. A. and Kelsey, H. M. (2012) Knickpoint and knickzone formation and propogation, South Fork Eel River, Northern California. Geosphere, 8, 403-416.

Goldspiel, J. M., \& Squyres, S. W. (2000) Groundwater sapping and valley formation on Mars. Icarus 148(1):176-192. https://doi.org/10.1006/icar.2000.6465

Goudge, T. A., Head, J. W., Mustard, J. F., and Fassett C. I. (2012a) An analysis of open-basin lake deposits on Mars: Evidence for the nature of associated lacustrine deposits and post-lacustrine modification processes. Icarus 219:211-229, doi:10.1016/j.icarus.2012.02.027.

Goudge, T. A., Mustard, J. F., Head, J. W., and Fassett C. I. (2012b) Constraints on the history of open-basin lakes on Mars from the composition and timing of volcanic resurfacing. J. Geophys. Res. 117:E00J21, doi:10.1029/2012JE004115.

Goudge, T.A., Mustard, J.F., Head, J.W., Fassett, C.I., Wiseman, S.M. (2015) Assessing the mineralogy of the watershed and fan deposits of the Jezero crater pale-olake system, Mars. $J$. Geophys. Res. 120:775-808. http://dx.doi.org/10.1002/2014JE004782.

Goudge, T.A., Milliken, R.A., Head, J.W., Mustard, J.F., Fassett, C.I. (2017) Sedimentological evidence for a deltaic origin of the western fan deposit in Jezero crater, Mars and implications for future exploration. Earth Planet. Sci. Let. 458:357-365.

Goudge, T. A., D. Mohrig, B. T. Cardenas, C. M. Hugues, and C. I. Fassett (2018) Stratigraphy and plaohydrology of delta channel deposits, Jezero crater, Mars. Icarus, 301:58-75.

Grotzinger, J.P., and Miliken, R.E. (2012) The sedimentary rock record of Mars: distribution, origins, and global stratigraphy. In: Grotzinger, J.P., Milliken, R.E. (Eds.), Sedimentary Geology of Mars. SEPM Spec. Publ., vol.102. Society for Sedimentary Geology, Tulsa, USA, pp.1-48.

Grotzinger, J.P., et al. (2015) Deposition, exhumation, and paleoclimate of an ancient lake deposit, Gale crater, Mars. Science, 350, aac7575. http://dx.doi.org/10.1126/science.aac7575. 
Gulick, V.C., V. R. Baker. 1990. Origin and evolution of valleys on Martian volcanoes, J. Geophys. Res. Solid Earth, 95 (B9), 14325-14344.

Gulick, V.C., 1998. Magmatic intrusions and a hydrothermal origin for fluvial valleys on Mars. J. Geophys. Res., 103, 19365-19387.

Gulick, V.C. 2001. Origin of the valley networks on Mars: a hydrological perspective. Geomorphology, 37, 241-268.

Gwinner, K., Scholten, F., Preusker, F., Elgner, S., Roatsch, T., Spiegel, M., Schmidt, R., Oberst, J., Jaumann, R., Heipke, C. (2010) Topography of Mars from global mapping by HRSC highresolution digital terrain models and ortho-images: characteristics and performance. Earth Planet. Sci. Lett. 294:506-519. http://dx.doi.org/10.1016/j.epsl.2009.11.007.

Hamilton, V. E., and Christensen P. R. (2005) Evidence for extensive, olivine-rich bedrock on Mars. Geology 33, 433-436, doi:10.1130/G21258.1.

Hargitai, H., Gulick, V., and Glines, N. (2017) Discontinuous drainage systems formed by precipitation and ground-water outflow in the Navua Valles and Southwest Hadriacus Mons,Mars. Icarus. DOI://10.1016/j.icarus.2017.03.005

Hargitai, H., Gulick, V., and Glines, N. (2018) The Geology of the Navua Valles Region of Mars. J Maps doi:10.1080/17445647.2018.1496858

Hargitai H.I, Gulick V.C., Glines N.H. (2019). Evolution of the Navua Valles region: Implications for Mars' paleoclimatic history. Icarus 330, doi.org/10.1016/j.icarus.2019.04.024

Hartmann,W.K., and Neukum, G. (2001) Cratering chronology and the evolution of Mars. Space Sci. Rev. 96:165-194.

Hauber, E., et al. (2005) Discovery of a flank caldera and very young glacial activity at Hecates Tholus, Mars. Nature 434 :356-358.

Hauber, E., Gwinner, K., Kleinhans, M., Reiss, D., di Achille, G., Ori, G.-G., Scholten, F., Marinangeli, L., Jaumann, R., Neukum, G. (2009) Sedimentary deposits in Xanthe Terra: implications for the ancient climate on Mars. Planetary Space Sci. 57:944-957, doi:10.1016/j.pss.2008.06.009.

Head, J. W., and Mustard J. F. (2006) Breccia dikes and crater-related faults in impact craters on Mars: Erosion and exposure on the floor of a crater $75 \mathrm{~km}$ in diameter at the dichotomy boundary. Meteorit. Planet. Sci. 41:1675-1690.

Hey, R. D. and C. R. Thorne (1986). Stable channels with mobile gravel beds, J. Hydraulic Engineering, 112:8 (671).

Hiesinger, H., and Head, J. W. (2004) The Syrtis Major volcanic province, Mars: Synthesis from Mars Global Surveyor data. J. Geophys. Res. 109:E01004, doi:10.1029/2003JE002143. 
Hoefen, T. M., Clark, R. N., Bandfield, J. L., Smith, M. D., Pearl, J. C., and Christensen P. R. (2003) Discovery of olivine in the Nili Fossae region of Mars. Science, 302:627-630, doi:10.1126/science.1089647

Horgan, B., Anderson, R. B., Ruff, S. W. (2018) The Nature, Origin, and Importance of Carbonatebearing Samples at the Final Three Candidate Mars 2020 Landing Sites, $2^{\text {nd }}$ Int. Mars Sample Return, Berlin, LPI contribution 2071.

Howard, A. D. (1986) Groundwater sapping on Mars and Earth, paper presented at Proc., and Field Guide, NASA Groundwater Sapping Conf., AD Howard, RC Kochel, and HE Holt, Eds., National Aeronautics and Space Administration, Flagstaff, Ariz., pp. vi-xiv.

Howard, A.D., Moore, J.M., Irwin, R.P. (2005) An intense terminal epoch of widespread fluvial activity on early Mars: 1.Valley network incision and associated deposits. J. Geophys. Res. 110 :E12S14. http://dx.doi.org/10.1029/2005JE002459.

International Mars Sample Return Objectives and Samples Team (iMOST), D. W. Beaty, M. M. Grady, H. Y. Mcsween, E. Sefton-Nash, B. L. Carrier, F. Altieri, Y. Amelin, E. Ammannito, M. Anand, L. G. Benning, J. L. Bishop, L. E. Borg,D. Boucher, J. R. Brucato, H. Busemann, K. A. Campbell, A. D. Czaja,V. Debaille, D. J. Des Marais, M. Dixon, B. L. Ehlmann, J. D. Farmer,D. C. Fernandez-Remolar, J. Filiberto, J. Fogarty, D. P. Glavin,Y. S. Goreva, L. J. Hallis, A. D. Harrington, E. M. Hausrath, C. D. K. Herd,B. Horgan, M. Humanyun, T. Kleine, J. Kleinhenz, R. Mackelprang, N. Mangold, L. E. Mayhew, J. T. Mccoy, F. M. Mccubbin, S. M. Mclennan,D. E. Moser, F. Moynier, J. F. Mustard, P. B. Niles, G. G. Ori, F. Raulin,P. Rettberg, M. A. Rucker, N. Schmitz, S. P. Schwenzer, M. A. Sephton,R. Shaheen, Z. D. Sharp, D. L. Schuster, S. Siljestrom, C. L. Smith,J. A. Spry, A. Steele, T. D. Swindle, I. L. Ten Kate, N. J. Tosca, T. Usui,M. J. Van Kranendonk, M. Wadhwa, B. P. Weiss, S. C. Werner, F. Westall,R. M. Wheeler, J. Zipfel, And M. P. Zorzano, 2019. The potential science and engineering value of samples delivered to Earth by Mars sample return. Meteoritics \& Planetary Science 54, Nr S1, S3-S152 doi: 10.1111/maps.13242

Irwin, R. P., R. A. Craddock, and A. D. Howard (2005b) Interior channels in Martian valley networks: Discharge and runoff productions. Geology 33:489-492, doi:10.1130/G21333.1.

Irwin, R.P., Howard, A. D. and Craddock, R. A. (2008) Fluvial valley networks on Mars. In "River confluences, tributaries and the fluvial network", S. P. Rice, A.G. Roy and B. L. Rhoads (eds), Wiley \& Sons, New York, 419-451 pp.

Johnson, K. N. (2016) Causes and Consequences of Meandering in Bedrock Rivers: how interactions between rock properties and environmental conditions shape landscapes. $\mathrm{Ph}$. D. Thesis, UC Santa Cruz.

Jones, A.P., McEwen, A.S., Tornabene, L.L., Baker, V.R., Melosh, H.J., Berman, D.C. (2011). A geomorphic analysis of Hale crater, Mars: the effects of impact into ice-rich crust. Icarus 211, 259-272. 
Kirk R. L., E. Howington-Kraus, M. R. Rosiek, J. A. Anderson, B. A. Archinal, K. J. Becker, D. A. Cook, D. M. Galuszka, P. E. Geissler, T. M. Hare, I. M. Holmberg, L. P. Keszthelyi, B. L. Redding, W. A. Delamere, D. Gallagher, J. D. Chapel, E. M. Eliason, R. King, A. S. McEwen, Ultrahigh resolution topographic mapping of Mars with MRO HiRISE stereo images: Meter-scale slopes of candidate Phoenix landing sites, 113 (E3) E00A24, doi.org/10.1029/2007JE003000.

Kite, E. S. Sneed, J. S. Mayer, and D. P. Wilson S. A. (2017) Persistent or repeated surface habitability on Mars during the Late Hesperian - Amazonian. Geophys. Res. Lett., 44, doi:10.1002/2017GL072660

Kite, E. S., Mayer, D. P., Wilson, S. A., Davis, J. M., Lucas, A. S , Stucky de Quay, G. (2019) Persistence of intense, climate-driven runoff late in Mars history, Science Advances, 5, eaav7710.

Kleinhans, M. G. (2005), Flow discharge and sediment transport models for estimating a minimum timescale of hydrological activity and channel and delta formation on Mars, J. Geophys. Res., 110, E12003, doi:10.1029/2005JE002521

Kleinhans, M.G., van de Kasteele, H.E., Hauber, E. (2010) Palaeoflow reconstruction from fan delta morphology on Mars. Earth Planet. Sci. Lett. 294:378-392. http://dx.doi.org/10.1016/j.eps1.2009.11.025.

Knighton, D. (1998) Fluvial forms and processes. Oxford Univ. Press, 384 pp.

Konsoer, K. M., J. LeRoy, D. Burr, G. Parker, R. Jacobsen, D. Turnel, Channel slope adjustment in reduced gravity environments and implications for Martian channels, Geology, 46, 183-186.

Kremer, C.H., Mustard, J.F., and Bramble, M.S., 2019, A widespread olivine-rich ash deposit on Mars: Geology, v. 47, p. 677-681, https:// doi .org /10 .1130/G45563.1

Laity, J. E., \& Malin, M. C. (1985) Sapping Processes and the Development of Theater-Headed Valley Networks on the Colorado Plateau. Geological Society of America Bulletin, 96(2):203-217.

Lamb, M. P., Dietrich, W. E., Aciego, S. M., Depaolo, D. J., \& Manga, M. (2008) Formation of Box Canyon, Idaho, by megaflood: Implications for seepage erosion on Earth and Mars. Science, 320(5879), 1067-1070. https://doi.org/10.1126/science.1156630

Lapotre, M. G. A. and Lamb, M. P. (2018) Substrate controls on valley formation by groundwater on Earth and Mars. Geology 46(6):531-534.

Lewis, K.W., Aharonson, O. (2006) Stratigraphic analysis of a distributary fan in Eber-swalde crater using stereo imagery. J. Geophys. Res., 111, E06001. http://dx.doi.org/10.1029/2005JE002558.

Loget, N., and Vand Den Driessche, J. (2009) Wave train model for knickpoint migration. Geomorphology, 106, 3-4, 376-382. 
Macdonald, G. A., Abbott, A. T., \& Peterson, F. L. (1983) Volcanoes in the sea: The geology of Hawaii. Honolulu, HI: University Of Hawaii Press.

Malin, M. C. and Carr, M. H. (1999) Groundwater formation of Martian valleys. Nature 397(6720), 589-591. https://doi.org/10.1038/17551

Malin, M.C. and Edgett, K.S. (2003) Evidence for persistent flow and aqueous sedimen-tation on early Mars. Science 302 :1931-1934. http://dx.doi.org/10.1126/science.1090544.

Malin, M.C., et al. (2007) Context Camera Investigation on board the Mars Re-connaissance Orbiter. J. Geophys. Res.112:E05S04. http://dx.doi.org/10.1029/2006JE002808.

Mandon, L., C. Quantin-Nataf, P. Thollot, N. Mangold, L. Lozac'h, G. Dromart, P. Beck, E. Dehouck, S. Breton, C. Millot, M.Volat, 2020. Refining the age, emplacement and alteration scenarios of the olivine-rich unit in the Nili Fossae region, Mars, Icarus, 336, doi10.1016/j.icarus.2019.113436

Mangold, N., Poulet, F., Mustard, J., Bibring, J.-P., Gondet, B., Langevin, Y., Ansan, V., Masson, Ph., Fassett, C., Head, J.W., Hoffmann, H., Neukum, G. (2007) Mineralogy of the Nili Fossae region with OMEGA/Mars Express data: 2. Aqueous alteration of the crust. J. Geophys. Res., 112:E08S04, doi:10.1029/2006JE002835.

Mangold, N., Ansan, V., Masson, Ph., Quantin, C., Neukum, G. (2008) Geomorphic study of fluvial landforms on the northern Valles Marineris plateau, Mars. J. Geophys. Res. 113:E08009, doi.org/10.1029/2007JE002985.

Mangold, N., 2012. Fluvial landforms on fresh ejecta craters. Planetary Space Science 62:69-85.

Mangold, N., Adeli, S., Conway, S., Ansan, V., and Langlais B. (2012a). A chronology of early Mars climatic evolution from impact crater degradation. J. Geophys. Res. 117 :E04003, doi:10.1029/2011JE004005.

Mangold, N., Kite, E.S., Kleinhans, M., Newsom, H., Ansan, V., Hauber, E., Kraal, E., QuantinNataf, C., and Tanaka, K. (2012b) The origin and timing of fluvial activity at the Eberswalde crater, Mars. Icarus, 220(2):530-551.

Mangold N., and Howard, A. D. (2013) Outflow channels with deltaic deposits in Ismenius Lacus, Mars. Icarus doi.org/10.1016/j.icarus.2013.05.040.

McLennan, S.M., Sephton, M.A., Allen, C., Allwood, A.C., Barbieri, R., Beaty, D.W., Boston, P., Carr, M., Grady, M., Grant, J., Heber, V.S., Herd, C.D.K., Hofmann, B., King, P., Mangold, N., Ori, G.G., Rossi, A.P., Raulin, F., Ruff, S.W., Sherwood Lollar, B., Symes, S., and Wilson, M.G. (2011) Planning for Mars returned sample science: final report of the MSR End-to-End International Science Analysis Group (E2E-iSAG). Astrobiology 12:175-230.

McEwen, A.S., et al. (2007) Mars Reconnaissance Orbiter's High Resolution Imag-ing Science Experiment (HiRISE). J. Geophys. Res.112, E05S02. http://dx.doi.org/10.1029/2005JE002605. 
Meyers, P.A and Ishiwatari, R. (1995) Organic matter accumulation records in lake sediments. In: A. Lerman et al., Editors, Physics and Chemistry of Lakes, Springer, pp. 279-328.

Michael G.G., and Neukum G., (2010) Planetary surface dating from crater size-frequency distribution measurements: Partial resurfacing events and statistical age uncertainty. Earth and Planetary Science Letters 294 (3-4):223-229.

Montgomery, D. R., and K. B. Gran (2001) Downstream variations in the width of bedrock channels, Water Resources Research, 37, 1841-1846.

Müller, G. (1966) The New Rhine Delta in Lake Constance. In: Delta in their geologic framework (Shirley and Ragsdale Eds), Houston Geol. Soc., Houston, TX, 107-124.

Murchie, S.L., et al. (2009) Compact Reconnaissance Imaging Spectrometer for Mars investigation and data set from the MarsReconnaissance Orbiter's pri-mary science phase. J. Geophys. Res. 114:E00D07. http://dx.doi.org/10.1029/2009JE003344.

Mustard, J. F., Poulet, F., Head, J. W., Mangold, N., Bibring, J.-P., Pelkey, S. M., Fassett, C. I., Langevin, Y and Neukum G. (2007) Mineralogy of theNili Fossae region with OMEGA/Mars Express data: 2. Ancient impact melt in the Isidis Basin and implications for the transition from the Noachian to Hesperian. J. Geophys. Res. 112:E08S03, doi:10.1029/2006JE002834.

Mustard, J. F., et al. (2008) Hydrated silicate minerals on Mars observed by the Mars Reconnaissance Orbiter CRISM instrument. Nature, 454:305-309, doi:10.1038/nature07097.

Mustard, J. F., Ehlmann, B. L., Murchie, S. L., Poulet, F., Mangold, N., Head, J. W., Bibring, J.-P., and Roach, L. H. (2009). Composition, mineralogy, and stratigraphy of Noachian crust around the Isidis basin. J. Geophys. Res., 114:E00D12, doi:10.1029/2009JE003349.

Mustard, J.F., et al. (2013). Report of the Mars 2020 Science Definition Team. 154 pp., posted July 2013, by the Mars Exploration Program Analysis Group (MEPAG) at http://mepag.jpl.nasa.gov/reports/MEP/Mars_2020_SDT_Report_Final.pdf.

Neukum, G., et al. (2004). HRSC: the high resolution stereo camera of Mars express. ESA SP1240, $17-35$.

Osterkamp WR, Hedman ER. 1982. Perennial-streamflow characteristics related to channel geometry and sediment in Missouri River basin. US Geological Survey Professional Paper 1242.

Pieri, D. C. (1980), Martian valleys: Morphology, distribution, age, and origin. Science, 210, 895897.

Poulet, F., Bibring, J.-P., Mustard, J. F., Gendrin, A., Mangold, N., Langevin, Y., Arvidson, R. E., Gondet, B., and Gomez C. (2005) Phyllosilicates on Mars and implications for early Martian climate. Nature, 438, 623-627, doi:10.1038/nature04274. 
Quantin, C., P. Allemand, N. Mangold, G. Dromart, and C. Delacourt (2005) Fluvial and lacustrine activity on layered deposits in Melas Chasma, Valles Marineris, Mars. J. Geophys. Res., 110 :E12S19 doi:10.1029/2005JE002440.

Quantin-Nataf, C., Craddock, R. A., Dubuffet, F., Lozac'h, L., Martinot, M. (2019). Decline of crater obliteration rates during early martian history. Icarus, 317, 427-433.

Reading, H.G. (Ed.), 1996, Sedimentary Environments: Processes, Facies and Stratigraphy, third ed. Blackwell Science, Boston, 688pp.

Roda, M., Kleinhans, M. G., Zegers, T. E., \& Oosthoek, J. H. (2014) Catastrophic ice lake collapse in Aram Chaos, Mars. Icarus, 236:104-121.

Rogers, A.D., Warner, N.H., Golombek, M.P., Head, J.W., III, and Cowart, J.C., 2018, Areally extensive surface bedrock exposures on Mars: Many are clastic rocks, not lavas: Geophysical Research Letters, v. 45, p. 1767-1777, https:// doi .org /10 .1002/2018GL077030

Rust, B.R. (1978) A classification of alluvial channel systems. Canadian Society of Petroleum Geologists, Memoir 5, 187-198.

Salese, F., Di Achille, G., Neesemann, A., Ori, G. G., \& Hauber, E. (2016) Hydrological and sedimentary analyses of well-preserved paleofluvial-paleolacustrine systems at Moa Valles, Mars. Journal of Geophysical Research: Planets 121(2) :194-232, doi: 10.1002/2015JE004891 .

Salese, F., Mangold, N., Kleinhans, M. G., de Haas, T., Ansan, V., Dromart, G. (2019a) Estimated minimum lifespan of the Jezero crater delta, Mars, $50^{\text {th }}$ Lunar Planet. Sci. Conf., LPI contribution 2132 .

Salese, F., Pondrelli, M., Neeseman, A., Schmidt, G., \& Ori, G. G. (2019b) Geological Evidence of Planet-Wide Groundwater System on Mars. Journal of Geophysical Research: Planets, 124(2) :374395, doi: 10.1029/2018JE005802 .

Salvatore, M. R., T. A. Goudge, M. S. Bramble, C.S. Edwards, J. L. Bandfield, E. S. Amador, J. F. Mustard, P. R. Christensen (2018) Bulk mineralogy of the NE syrtis and Jezero crater regions of Mars derived trhough thermal infrared spectral analyses. Icarus 301:76-96.

Saper, L., and J. F. Mustard (2013) Extensive linear ridge networks in Nili Fossae and Nilosyrtis, Mars: Implications for fluid flow in the ancient crust. Geophys. Res. Lett. 40:245-249, doi:10.1002/grl.50106.

Schon, S.C., Head, J.W., and Fassett, C.I. (2012) An overfilled lacustrine system and progradational delta in Jezero crater, Mars: implications for Noachian climate. Planet. Space Sci., 67:2845. http://dx.doi.org/10.1016/j.pss.2012.02.003. 
Segura, T.L., Toon, O.B., Colaprete, A. (2008). Modeling the environmental effects of moderatesized impacts on Mars. Journal of Geophysical Research 113 :E11007.

Sharzad, S., Kinch, K. M., Goudge, T. A., Fassett, C. I., Needham, D. H., Quantin-Nataf, C., Knudsen, C. P. (2019) Crater statistics on the dark-toned, mafic-floor unit in Jezero crater, Mars. Geophys. Res. Let. 46 :2408-2416.

Silberman, E., R. Carter, H. Einstein, J. Hinds, R. Powell (1963). Friction factors in open channels, J. Hydraul. Eng., 89, 97-143.

Smith, D.E., et al. (2001) Mars Orbiter Laser Altimeter: experiment summary after the first year of global mapping of Mars. J. Geophys. Res. 106(23):23,689-23,722.

Summons, R.E., Amend, J.P., Bish, D., Buick, R., Cody, G.D., Des Marais, D.J., Dromart, G., Eigenbrode, J.L., Knoll, A.H., Sumner, D.Y. (2011) Preservation of martian organic and environmental records: final report of the Mars biosignature working group. Astrobiology 11:157181. http://dx.doi.org/10.1089/ast.2010.0506.

Tanaka, K.L. (1982) A new time-saving crater-count technique with application to narrow features. NASA Tech. Memo., TM-85127, pp. 123-125

Tanaka, K.L., Skinner, J.A., Dohm, J.M., Irwin, R.P., Kolb, E.J., Fortezzo, C.M., Platz, T., Michael, G.G., Hare, T.M. (2014) Geologic Map of Mars, Scale 1:20,000,000. U.S. Geological Survey Scientific Investigations Map SIM 3292. Available at http://pubs.usgs.gov/sim/3292.

Tarnas, J. D., Mustard, J. F., Lin, H., Goudge, T. A., Amador, E. S., Bramble, M.S.,etal.(2019).Orbital identification of hydrated silica in Jezero crater, Mars. Geophysical Research Letters, 46. https://doi.org/10.1029/2019GL085584

Valla, P., P. A. Van Der Beek, D. Lague (2010) Fluvial incision into bedrock: Insights from morphometric analysis and numerical modeling of gorges incising glacial hanging valleys (Western Alps, France). Journal of Geophysical Research, American Geophysical Union, 2010, 115, pp.F02010.

Vaz, D. A., G. Di Achille, B. M. Hynek, W. Nelson, R. E. Williams (2018). Global morphometric survey of Martian deltaic deposits: Methods and validation, $49^{\text {th }}$ Lunar Planet. Sci. Conf., Houston, \#2083.

Willett, S. D., S. W. Mc Coy and H. W. Beeson (2018). Transience of the North American High Plains landscape and its impact on surface water, Nature, 561, 10.1038/s41586-018-0532-1.

Williams, G.P., 1988, Paleofluvial estimates from dimensions of former channels and meanders, in Baker, V.R., et al., eds., Flood geomorphology: New York, John Wiley and Sons, p. 321-334 
Wilson, L., Ghatan, G. J., Head III, J. W., and Mitchell, K. L. (2004) Mars outflow channels: A reappraisal of the estimation of water flow velocities from water depths, regional slopes, and channel floor properties, J. Geophys. Res., 109, E09003, doi:10.1029/2004JE002281.

Table 1: Main morphometric parameters measured in this study and compared to previous studies. Previous studies from Fassett and Head, 2005 and *Goudge et al., 2015 measured channels on the depositional fan.

\begin{tabular}{|l|l|l|}
\hline & Previous studies & This study \\
\hline Volume fan & $5 \mathrm{~km}^{3}$ & $\sim 4 \mathrm{~km}^{3}$ \\
\hline Lake level & $-2395 \mathrm{~m}$ & $\sim-2400 \mathrm{~m}$ \\
\hline $\begin{array}{l}\text { Volume eroded by } \\
\text { valleys }\end{array}$ & $58 \mathrm{~km}^{3}$ & $\begin{array}{l}\text { Lower valley }: 3 \mathrm{~km}^{3} \\
\text { Upper Valley }: 53 \mathrm{~km}^{3}\end{array}$ \\
\hline Watershed area & $\begin{array}{l}15,000 \mathrm{~km}^{2} \text { (all) } \\
* 12,000 \mathrm{~km}^{2}(\text { western } \\
\text { watershed only) }\end{array}$ & $\begin{array}{l}\sim 6,500 \mathrm{~km}^{2} \text { western } \\
\text { watershed (see section } \\
3.1 .3)\end{array}$ \\
\hline Channel width & $50-100 \mathrm{~m} \mathrm{(on} \mathrm{the} \mathrm{fan)}$ & $\begin{array}{l}200-500 \mathrm{~m} \text { (upstream } \\
\text { Jezero entrance) }\end{array}$ \\
\hline Discharge rates & $\begin{array}{l}170-400 \mathrm{~m}^{3} . \mathrm{s}^{-1} \text { (locally on } \\
\text { the fan) }\end{array}$ & $\begin{array}{l}900-21,000 \mathrm{~m}^{3} . \mathrm{s}^{-1} \\
(\text { see Tab. } 2 \text { and section 3.3) }\end{array}$ \\
\hline $\begin{array}{l}\text { Strict minimum } \\
\text { period of activity } \\
\text { for fan formation }\end{array}$ & $11 \mathrm{y}$ & $\begin{array}{l}4 \mathrm{y} \\
\text { (see section } 5.1)\end{array}$ \\
\hline
\end{tabular}

Table 2: Channel discharge rates at four locations along the lower valley at locations Q1 and Q2 (in Figure 3c) and at the entrance channel in Figure $6 \mathrm{c}$ (location of the dotted line). Three methods were used: The empirical width/depth ratio (Irwin et al., 2005), the Manning equation (Wilson et al., 2004), and the Darcy-Weisbach equation (Kleinhans et al., 2010).

\begin{tabular}{|l|l|l|l|l|l|}
\hline Location & Width (m) & Slope & Discharge & rates & $\mathbf{( m}^{\mathbf{3}}$.s \\
\hline & & & Empirical & Manning & Darcy-Weisbach \\
\hline Q1 (Fig. 3c) & 500 & 0.007 & 2826 & 21303 & 9954 \\
\hline Q2 (Fig. 3c) & 200 & 0.017 & 924 & 4161 & 1778 \\
\hline $\begin{array}{l}\text { Q3 (Entrance } \\
\text { channel) }\end{array}$ & 200 & 0.014 & 924 & 3776 & 1702 \\
\hline
\end{tabular}

